\title{
Guilds in the transition to modernity: The cases of Germany, United Kingdom, and the Netherlands
}

\author{
Marcel Hoogenboom ${ }^{1}$ - Christopher Kissane ${ }^{2}$. \\ Maarten Prak $^{3}$ - Patrick Wallis ${ }^{2}$. Chris Minns ${ }^{2}$
}

\begin{abstract}
One important aspect of the transition to modernity is the survival of elements of the Old Regime beyond the French Revolution. It has been claimed that this can explain why in the late nineteenth and early twentieth centuries some Western countries adopted national corporatist structures while others transformed into liberal market economies. One of those elements is the persistence or absence of guild traditions. This is usually analyzed in a national context. This article aims to contribute to the debate by investigating the development of separate trades in Germany, the United Kingdom, and The Netherlands throughout the nineteenth century. We distinguish six scenarios of what might have happened to crafts and investigate how the prevalence of each of these scenarios in the three countries had an impact on the emerging national political economies. By focusing on trades, rather than on the
\end{abstract}

Marcel Hoogenboom

m.j.m.hoogenboom@uu.nl

Christopher Kissane

christopher.kissane@gmail.com

Maarten Prak

m.prak@uu.nl

Patrick Wallis

p.h.wallis@1se.ac.uk

Chris Minns

C.Minns@1se.ac.uk

1 Department of Interdisciplinary Social Science, Utrecht University, Heidelberglaan 1, 3584 CSUtrecht, The Netherlands

2 Department of Economic History, London School of Economics and Political Science, Houghton Street, London WC2A 2AE, UK

3 Department of History and Art History, Utrecht University, Drift 6, 3512 BSUtrecht, The Netherlands 
national political economy, our analysis demonstrates that in each country the formation of national political economies and citizenship rights was not the result of a national pattern of guild survival. Rather, the pattern that emerged by the end of the nineteenth century was determined by the balance between old and new industries, and that between national and regional or local government.

\section{Keywords Guilds · Citizenship · Political economy · Modernization, Europe}

The nineteenth century is often portrayed as the era of laissez-faire, of unbridled capitalism, a Smithian paradise of free markets and minimal government interference. Even if this picture held true in some places and decades, it still provides a fundamentally misleading portrait of a century that witnessed the emergence of political parties, cooperatives, as well as labor unions and employer organizations. These latter organized interests started to clamor for regulations in multiple areas: workplace safety, limitations on child labor and working hours, and consumer safety, welfare, and skillsformation. The emerging arrangements were remarkably varied across Europe and in recent decades historians, sociologists, and political scientists have attempted to explain this wide array of national political economies and indeed the electoral systems underpinning them. This literature has concentrated on explaining why some Western countries adopted corporatist structures or "coordinated market economies" while others transformed into "liberal market economies" (Hall and Soskice 2001). In their analyses, scholars identify a range of factors that may explain differences between national systems, like religious and non-economic cleavages (Rokkan 1970; Boix 1999), the presence of strong rural cooperatives (Katzenstein 1985; Crouch 1993), specific types of labor unions (Guinnane and Timothy 2001), a large-skill-based export sector (Crouch 1993; Thelen 2004) and the persistence of craft guild traditions.

On the persistence of craft guild traditions, Cusack, Iversen \& Soskice (2007, pp. 374 and 379), for example, have theorized that in the late nineteenth and early twentieth centuries in some Western countries "a strong guild tradition [...] in complex ways" led to the emergence of strong and cooperative employers' associations and labor unions, which "were accustomed to solving collective action problems through associations" and this in turn benefitted the choice of an electoral system based on proportional representation over a majority system. The problem with this type of argument is not that it is necessarily wrong, but that the underlying mechanisms are poorly documented. By filling the knowledge gap on early forms of citizenship in the formation of twentieth-century political economies in three northwestern European countries, this article aims to contribute to the debate by investigating the transformation of Old Regime craft guilds into their nineteenth-century successors.

The argument about the historical link between the presence or absence of guild traditions and national political economies is essentially addressing the transformation of citizenship rights. Before 1800, in many Western European countries guilds not only regulated and monitored access to economic production; guild membership also implied access to local political citizenship and social support (Prak 2018). Hence craft guilds could be seen as the bearers of citizenship rights, which at the time were consolidated on the local, instead of the national level. Similarly, by linking (or not linking) occupational status to access to political and economic decision-making and to 
social protection, the Western European political economies and electoral systems that emerged in the late nineteenth and early twentieth centuries were a reflection of the distribution of citizenship rights at the national level.

Largely following Marshall (1950), this article distinguishes three types of citizenship rights: economic, political, and social. Economic rights (a subcategory of Marshall's "civil rights," which also includes juridical rights, which are not addressed here) refer to rights to occupation and settlement of a business, organize interest groups, and participate in collective skills-formation. Political rights include the right to political association and to participate in political decision-making by electing representatives or otherwise. Social rights entail the right to receive social support from the community in times of need. Given the complexity of the question and the space available, the data come from three countries - Germany, the United Kingdom and The Netherlands - that represent three distinct trajectories of industrialization and democratization. These countries have been selected because they represent three distinct political economies, both before and after the transition. England was the first country to develop modern industry and guilds were already weakened there before 1800 . The Netherlands transformed from a federal republic into a centralized monarchy and was a late industrializer during the nineteenth century. Germany remained a federation and although another late industrializer, it was one of the leaders of the so-called second Industrial Revolution in the second half of the nineteenth century. The case selection thus offers a range of possibilities, without claiming to be exhaustive. Including other countries like France or Spain would have enriched the range of samples but, we believe, not affect the analytical results in any fundamental way.

By investigating the role of guild traditions in the formation of national political economies and citizenship right systems, this article aims at contributing to the "neoinstitutionalist" literature on various "types" of national political economies - or "varieties of capitalism" (Hall and Soskice 2001), or "worlds of welfare capitalism" (Esping-Andersen 1990) - but in a distinctive manner. Central to this literature is the idea of "path dependence" (Mahoney 2000; Thelen 2004), which in this literature is usually applied to explain the "stickiness" of existing political economy institutions and their inability to change (e.g., Pierson 2000), but generally not to clarify the specific origins of these institutions, which are usually explained by applying a "power resources" approach (Esping-Andersen 1990; Pierson 2000; Thelen 2004).

At first sight, abandoning the path dependence approach when it comes to explaining the origins of national political economy institutions seems plausible. After all, most countries had hardly any national socio-economic institutions when "modern" national political economies were forged. Yet the absence of a national path does not necessarily imply that national political economies emerged out of the blue. As Scott (2008, p. 94) puts it, "[i]nstitutions do not emerge in a vacuum; they always challenge, borrow from, and, to varying degree, displace prior institutions". As this article aims to demonstrate, when national political economy institutions were built, frequently a path or paths did exist - but not at the national level. These paths had been trodden by local and trade communities and had long historical lineages. Yet when in the course of the nineteenth and early twentieth centuries "modern" national political economies were created, often various paths (or "worlds": Sabel and Zeitlin 1985, 2002) were available. This article seeks to explain how in the three selected countries a specific path could dictate the course of national political economy and citizenship formation and others 
could not. The central question in this article therefore is: "How did guild traditions shape the transition to modern society, including the transformation of local into national citizenship rights, in Western European countries?"

The article is structured as follows. In the next section, we briefly characterize the functions of craft guilds in early modern Western Europe and develop an analytical tool that can help us to investigate their fate in the nineteenth century. This search will result in six scenarios on the development of trades, to be analyzed and illustrated next with descriptions of their nineteenth-century development. We then focus on the prevalence of these six scenarios in the three countries we selected and their influence on the emerging national political economies. The final section contains the discussion and conclusion.

\section{Analyzing guilds and their abolition}

Until about 1800, in many Western European countries craft guilds were the bearers of local citizenship rights. Already in the Middle Ages guilds were intimately linked with citizenship, either because citizenship was a prerequisite to become a guild master or because a guild apprenticeship qualified a person for local citizenship (Epstein 1991; Kluge 2007). Also on an ideological level, guilds and citizenship were closely intertwined. In many places, the incorporated trades were known as "citizen's trades," and in petitions guildsmen portrayed their guild membership as part of their civic identity and as the economic underpinning of their middle-class existence, which in turn was seen as appropriate for citizens (Prak 1996, 2018). Economically, the guilds might coordinate the setting of prices and wages, but by the eighteenth century this was relatively unusual. The guild's economic activities tended to be in the realm of coordination rather than in direct market interventions. One area where this is particularly clear is the organization of apprenticeship, according to some experts the guilds' single most important economic contribution (Epstein 1998). Politically, the guilds in some towns and cities had a direct say in the selection of officials; sometimes their own officials were members of the town council. Still, such direct representation happened only in a minority of towns. Elsewhere, guilds had to be satisfied with lobbying the local government, which could be almost as effective (Van Nierop 2007). Socially, guilds had two roles to play in pre-modern towns. From the very start, many guilds provided some sort of social security to their members. This could be informal help, or completely formalized to the extent that a separate account was maintained to handle the dedicated funds. In some places journeymen had their own welfare schemes (Van Leeuwen 2012). Guilds' second social contribution was the creation of a sense of belonging. This may be difficult to pin down, but the documents handed down to us speak over and over again of "brothers" and "sisters," urging members to "love" each other, and describing the numerous social activities that went on in guilds (Rosser 2015).

This brief characterization of pre-1800 guilds and their functions largely holds for the early modern period in most of Western Europe. On the eve of the French Revolution, only in the United Kingdom had many guilds already become ineffective, largely due to the inability or unwillingness of the authorities to uphold the charters and regulations that had previously underpinned their powers (Rule 1981). In The Netherlands 
and many of the German states guilds were formally abolished during the period of French occupation (1794-1815). In The Netherlands, guilds would never be formally reinstated, although many survived informally. In most German states the authorities were following a zigzag course in the nineteenth century, alternating between different attempts to stimulate economic development, either by lifting all sorts of protective regulations or by reinstalling guilds and guild-like regulations, particularly in times of social upheaval.

What happened to citizenship rights in these countries after guilds and their regulations had been formally or de facto abolished? In theory, the abolition had two major consequences. First, access to a trade was no longer regulated by formal rules, and if economic relations were not immediately reorganized by a strong national state, economic and social rights remained ambiguous. In theory they were accessible to all and sundry, but whether this also was true in practice remains to be seen. Second, political citizenship rights became generally more limited because of franchise thresholds and simultaneously less significant as local authorities lost much of their autonomous powers to national institutions, which were even less accessible to voters in most countries during much of the nineteenth century. In other words, the changes of the nineteenth century may have given more people more rights in theory, but in practice fewer rights were available to fewer people, because of the abolishment of the civic institutions that previously gave them political and economic agency.

According to Crouch (1986, p. 182), if we want to understand what happened to citizenship rights in various Western European countries we must look at the temporal "gap" between the disappearance of guilds and guild-like regulations, and the emergence of national political economies:

[T] he longer the interval, or the sharper the breach, between the destruction of ancient guild and Ständestaat institutions and the construction of typically "modern" interest organizations, the more committed did the state become to liberal modes of interest representation, and the less likely to tolerate sharing political space; the less likely were modern organizations to target their ambitions on participation of that kind; and the less likely were neo-corporatist institutions to become established.

Essentially, Crouch's theory of gaps, reformulated in neo-institutionalist terms, addresses the availability of a path or paths, but leaves open the possibility that no such path existed and that the construction of national political economies was a matter of political actors and social movements struggling over whose preferences for a national political economy were to be implemented. In that sense, Crouch's theory is an (early) attempt to reconcile path dependence theory with the power resources approach (see also Crouch 2001, 2005).

While Crouch's theory of gaps is an interesting starting point, in its current form it is too broad to be tested. First, in his analysis Crouch looks at nineteenth-century countries as homogeneous entities, ignoring that national political economies emerged from a constellation where the economy was regulated at the local level and where variation within countries was therefore substantial. Hence our analysis should address not only how "old" socio-economic and political regulatory mechanisms were replaced by "new" ones, but also how and whether regulatory mechanisms were transplanted from the local to the national level, and how local variety eventually transformed into 
national unity. Moreover, in the pre-1800s era the extent to which trades were regulated by means of guilds and similar organizations not only diverged between cities and towns within single countries, but also within the cities and towns themselves. Therefore, it makes more sense to start our investigation with a focus on trades. The crucial questions here are:

1. To what extent was a specific trade regulated by means of guilds or guild-like regulations in the pre-1800 period?

2. To what extent was a specific trade regulated by means of guilds or guild-like regulations after 1800 ?

Second, Crouch implicitly assumes that the abolition of the guilds in the late eighteenth or in the nineteenth century automatically meant the end of the old regulatory mechanisms. Yet in practice artisans often remained capable of regulating access to their trade and skills-formation for a long time, even after guilds were formally abolished (Koselleck 1967; Crossick 1997). Breuilly (1985) thinks that the extent to which artisans of a formally abolished guild were capable of retaining their regulating powers related to the characteristics of the production processes in that trade. The crucial question here is: Could production processes be easily industrialized, i.e., standardized and mechanized? Whereas some crafts were largely destroyed or considerably transformed by industrialization, others were hardly affected by it. A third question thus arises that needs to be answered:

3. To what extent could production processes in a specific trade be industrialized?

When combining the possible answers to our three questions, we can distinguish six scenarios for what may have happened to individual trades during the nineteenth century (see Table 1).

In the next section we demonstrate that these scenarios actually unfolded in the three countries we selected and we analyze what the scenarios actually meant for the economic, political, and social citizenship rights of masters (or "employers"), journeymen, and apprentices (or "workers"). Then we analyze how, throughout the

Table 1 Craft trades in the nineteenth century: six scenarios

\begin{tabular}{llll}
\hline & $\begin{array}{l}\text { Strong guild } \\
\text { before 19th century? }\end{array}$ & $\begin{array}{l}\text { Guild or informal regulatory } \\
\text { mechanisms effective deep } \\
\text { into 19th century? }\end{array}$ & $\begin{array}{l}\text { Production processes } \\
\text { easy to industrialize? }\end{array}$ \\
\hline 1. Old artisanism & Yes & Yes & No \\
2. Industrialized artisanism & Yes & Yes & Yes \\
3. Liberalized artisanism & Yes & No & No \\
4. Destroyed artisanism & Yes & No & Yes \\
5. New artisanism & No & - & No \\
6. New industrialism & No & - & Yes \\
\hline
\end{tabular}


nineteenth century, the developments in the economic and political spheres coincided and shaped national political economies in these countries. As we demonstrate, decisive was not only how and whether individual trades in our three countries and the regulatory mechanisms in these trades transformed in the nineteenth century, but also which of these trades came to dominate the development of national political economies by the end of the century.

\section{Artisans, economic liberalization, and industrialization in the nineteenth century}

Based on the theoretical exploration in the previous section we theorize that in the nineteenth century trades may have developed along six lines that we call "scenarios". In this section we will explore these scenarios: What happened to the access to the trade and to the position of masters, journeymen, and apprentices? What interest organizations developed? And what did that mean for labor relations? (For a summary of the key characteristics of each scenario, see Table 2.)

\section{Old artisanism}

The trades that most obviously contradict the standard story of a nineteenth century of free markets and industrialism are those where old guilds or guild-like regulatory mechanisms formally or informally survived throughout the century, and where mechanization of production processes was (almost) impossible. In some cases, guilds or guild-like regulatory mechanisms survived for political reasons, as in Prussia, where the authorities saw guilds as a bulwark against radicalism and the organization of workers (Bergmann 1973). Guild regulations could also survive because of the strategic value of the trade for local authorities, for example if they were considered essential to social peace or hygiene (Van Genabeek 1994). There were also various reasons why production processes in these trades were not or hardly industrialized, for example because industrialization was technically not (yet) possible or unnecessary because the market was purely local (Breuilly 1985).

An example displaying virtually all of the above was the butchers' trade in the City of London. Here, as in many British cities and towns (Grady 2000; MacLachlan 2004), throughout the nineteenth century small-scale butchers managed to ward off a number of threats to their independence and artisanism, so that "London entered the twentieth century as it had entered the nineteenth, with a meat supply that was only partially inspected and with hundreds of small-scale slaughter-houses dispersed throughout the metropolitan region" (MacLachlan 2007, p. 254). Part of the explanation for this continuity was the stable organization of London slaughterers, cutters, and retailers, which went back to the tenth century when the Worshipful Company of Butchers had been established. From the fourteenth century, this guild, or "livery company," as guilds in the City of London were called, had been formally entitled to regulate labor conditions, training, wages, and quality standards in the butchers' trade in the City and one mile around it. As the City expanded massively during the seventeenth, eighteenth, and nineteenth centuries, "non-freemen"-butchers who lacked membership in the Company because they had not been formally apprenticed-opened 


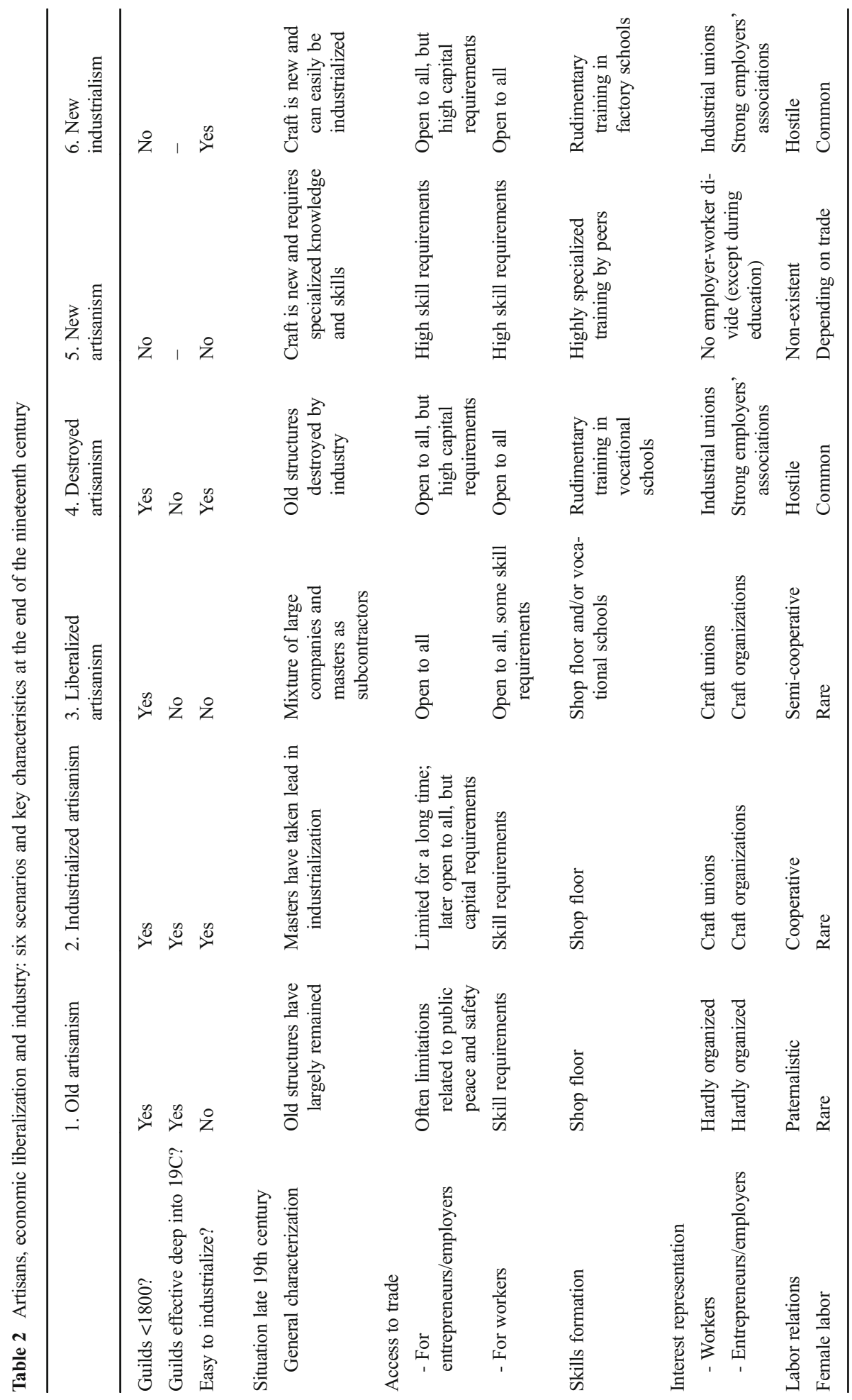


up shops outside the City boundaries, but as the freemen largely controlled the supply of livestock on the hoof at the Smithfield cattle market, and after 1855 the Metropolitan Cattle Market in Islington, other butchers in the City were completely dependent on the Company. As a result, despite the formal abolition of the guilds in the United Kingdom in 1799, guild-like structures remained dominant in London butchery, even when from the 1850 s trade liberalization allowed the importation of large quantities of foreign cattle to the United Kingdom (Jones 1976).

From the 1820s, the biggest threat to the Company's dominance were campaigns by engineers, physicians, reformers and local residents to abolish the large number of private slaughter-houses in favor of large public abattoirs, out of public order concerns (daily herds of livestock heading for Smithfield market were blocking the City streets) and for public health reasons (livestock and slaughter offal were considered health risks). Throughout the nineteenth century, London butchers and their organizations managed to bat away such criticisms by playing public opinion and local authorities (MacLachlan 2007). The butchers claimed that centralizing slaughtering in a limited number of public abattoirs would increase, not decrease, public health risks. In a prerefrigeration age, meat would spoil quickly if waiting for customers, a risk that could be limited if local butchers "stored" the meat on the hoof in their businesses. Butchers also appealed to the widespread laissez-faire belief by portraying themselves as defenders of private enterprise against government intrusion. The success in averting change enabled London butchers to continue their trade throughout the nineteenth century without major changes in their workshops and production processes (Jones 1976).

The case of the London butchers is not at all unique. The fate of butchers in Berlin was largely similar, although in Berlin public authorities were more deliberately and explicitly protecting the trade as part of a wider policy to prevent radicalism and workers' organization (Bergmann 1973; Brantz 2003). In all three countries we find, throughout the nineteenth century, brewers, grocers, bakers, and similar tradespeople maintaining control over the access to product and labor markets because they met basic demands of the domestic population (cf. Van Zanden and Van Riel 2004). As they managed to maintain control over access and production was very difficult to mechanize, production processes and labor relations remained largely unaltered.

Yet the trades that followed this scenario did not contribute much to the continuation of guild traditions within national political economies, because they tended to operate at the local level, and their interest representation was also primarily directed at the local political arena. It seems that at least some substantial change was necessary to "unlock" trades from their local orientation and to produce organizational forms - employers' associations, labor unions, corporatist structures - capable of influencing developments at the national level (Kocka 1984). Such situations could be found among the crafts that followed the second and third scenarios-industrialized artisanism and liberalized artisanism.

\section{Industrialized artisanism}

The second scenario also concerns trades in which, before 1800, guilds functioned as local economic (semi-)monopolies that formally or informally remained deep into the nineteenth century. The crucial difference with the first scenario (old artisanism) is that production processes, or parts of them, in these trades were relatively easy to 
standardize and to mechanize. In the course of the nineteenth century, therefore, when new technologies became available, industrialization in these trades could take place within a more or less "traditional" framework.

An example of industrialized artisanism was the printing trade in the German lands, which was concentrated in cities like Leipzig and Frankfurt. Even though prenineteenth-century German printers often lacked independent guilds, the trade had strong regulations and protection through the Postulat, "a statute with a long tradition" that established training times and procedures, and gave journeymen printers the right to take on and to train apprentices. Journeymen printers engaged in long spells of journeying, both to learn skills and because a broad knowledge and cosmopolitanism was considered essential to their skill. Journeymen were thus the main employees of "principals" - publishers, booksellers or editors who owned the German printing shops (Welskopp 2010, p. 65). In most of Germany, these typical guild-like traits remained relevant far into the nineteenth century - including the practice to ban women from the trade. This happened despite gradual erosion of the Postulat throughout the nineteenth century and a significant increase in the number and size of printing workshops from the 1830 s, due to innovations in printing presses and paper manufacturing. After 1850, the social distance between what were now employer and employees increased, and the latter, now that "the chance for a journeyman printer or typesetter to set up shop for themselves [became] slim," organized into "craft unions" (ibid., p. 64; see also Kocka 1990). These unions had a clear focus on the trade itself and on improving material conditions for printers, and they had a strong craft identity that viewed printing as an "art" threatened by modern commerce. As previously under the Postulat, these unions were engaging in collective bargaining with employers already in the 1860s; this continued after printers' unions were integrated into national labor union federations in the late nineteenth century (Beier 1968).

The development of the German printing trade is illustrative of a considerable number of trades in all three countries, such as silk-weaving in Britain (Jones 1987), diamond-cutting and printing in the Netherlands (Hofmeester 2004; Knotter 1993), and many highly specialized trades in Germany, such as metallurgy and production of cutlery, optical equipment, and weapons. What these trades had in common was that, during much of the nineteenth century, protective (guild-) regulations limited the access - of both employers and workers - to the trade. When the industrialization of production processes in these trades commenced and when protective regulations were gradually lifted in mid-century, enterprising masters were at the center of developments (Crossick 1997). The occupational group meanwhile continued to exert large influence over access via skill-formation; specific skills remained indispensable in these trades, despite the partial mechanization of production processes (Herrigel 1996).

With their workshops gradually turning into larger-scale production units, enterprising masters became the "employers" of artisan "workers", who nevertheless retained their skills and organizational identity and who often considered themselves to be part of a "labor aristocracy". One consequence was that unionization in these trades, which often started early, resulted in typical craft unions that resembled pre-1800s organizations of journeymen, focused on bonding, entertainment, and organizing mutual insurance funds. After 1850, when economic and population growth enabled employers in these trades to hire increasing numbers of apprentices - often underpaid and poorly trained, never outgrowing the apprentice status - the craft unions transformed into 
"modern" labor unions. These unions, which usually organized relatively large percentages of the workers in the trade, sought to defend the "traditional rights" of the artisan workers, if necessary by means of trade-wide strikes (Breuilly 1985; Lenger 1991; Leisink and Leisink 1994). Despite the concentration on their own trades, by the turn of the twentieth century these labor unions were amongst the first to establish national organizations, which in turn greatly contributed to the establishment of national labor union federations (Hueting et al. 1983; Hanagan 1988).

Meanwhile, masters/employers in these trades were generally slow to organize, arguably since they were unfamiliar with the rebelliousness of the artisan workers and their organizations. Instead of establishing their own associations, they initially attempted to frustrate union activity by banning union members from their companies (Yarmie 1980; Knotter 1993). When this failed, employers' associations, which had often grown directly out of guilds (Herrigel 1993), sought to pacify the unions by trying to re-establish "traditional" modes of conflict reconciliation, often successfully. For example, in the 1900s Dutch labor unions and employers' associations in the printing trade signed the first collective local labor agreements, and they were also the first to conclude at a national level such an agreement containing far-reaching regulations like compulsory membership in their organizations for both workers and employers and trade-wide binding administration of justice (Leisink and Leisink 1994).

\section{Liberalized artisanism}

The third scenario covers trades where guilds were strong before 1800 but already lost their effectiveness in the early nineteenth century. As in the first scenario of old artisanism, industrialization of production processes in these trades proved difficult for technical reasons or unnecessary because they produced predominantly for local markets. And as in the first scenario, this situation caused skills, rather than capital and machines, to remain the trades' key production factor. Yet, due to the early abolition of protective regulations, artisans were no longer capable of controlling product and labor markets. This had two far-reaching consequences. First, since masters could no longer control product markets, competition increased markedly. Consequently, despite the limited social divide between masters/employers and journeymen/workers, labor relations were constantly under pressure. Second, as masters could no longer control labor markets the old apprentice system was undermined, causing skills-formation to become problematic in these trades (Crossick 1997).

An example of this scenario was the building trade in the Netherlands and the United Kingdom. During the nineteenth century, mechanization in this trade was low, since at least in the century's first decades much of the work concerned repairs and renovations, while new constructions usually required made-to-measure work (Knotter 1984; Powell 1996). Building in both countries remained largely reliant on hand tools and manual work, and only after 1850 did technical developments gradually start to affect the trade. The 1860s saw the introduction of some standardized parts in plumbing and carpentry. Standardization and the use of pre-fabricated parts increased thereafter: window frames, bricks, and other materials became more regular. Some powered machinery began to be used, like steam cranes and drilling machines, but this only had a real impact toward the end of the century (McKenna and Rodger 1985). 
The real change in this period concerned the organizational structure of labor relations in the trade. Until the early nineteenth century, apprenticeship requirements had formally (e.g., The Netherlands) or informally (e.g., the United Kingdom) regulated access to the building trade and skills-formation. The abolition of these requirements had little initial impact: small localized firms with a "traditional" masterjourneymen relationship continued to dominate the trade. However, when demand exploded midcentury due to population growth, the commissioning of public works and large companies' investments, small builders increasingly became subcontractors of larger firms that took on huge projects, and as a result they were forced to specialize (Knotter 1993; Powell 1996). Growing demand also opened up the market for new competitors, who felt less obliged to adhere to traditional informal agreements about wages, skills-formation and so on. As a result, the employment of non-skilled workers, pressure on wages, and incidence of temporary contracts all increased. Both in The Netherlands and the United Kingdom this led to the establishment of labor unions along occupational lines, seeking to preserve members' traditional rights. The same developments also eroded the apprenticeship system in the building trade. Employers and local authorities, increasingly anxious about the situation, launched vocational schools, which in subsequent decades rapidly spread across the country but could not entirely replace the old apprenticeship system (Schalk 2016).

The scenario of liberalized artisanism can be observed in other trades where mechanization of production processes was only partially possible or necessary, like shoemaking and tobacco processing in the Netherlands (Van der Ven 1953) or the clothing industry in the Netherlands (ibid.) and Germany (Quataert 1985). In these trades too, limited industrialization resulted in a "dualization," with medium-sized factories producing the raw materials to manufacture artisan products in small workshops. In such workshops, labor conditions were comparable with those under the first scenario (old artisanism), but relations were tenser. Due to the inability to regulate access to the trade, for example, via skills-formation, workers from outside the occupational group could also enter (cf. Breuilly 1985; Kocka 1984). Initially, artisan workers resisted this intrusion of their trades by trying to limit access, for example by establishing "production cooperatives," i.e., associations of artisans who tried to sell their labor collectively. When these failed, workers teamed up with newcomers against employers by establishing — often explicitly socialist or syndicalist-labor unions (Kocka 1984; Lenger 1991). Yet despite the unions' militancy, labor conflict in these trades would only rarely resemble the outright class wars typical of our fourth and sixth scenarios. Eventually the small social and spatial distance between employer and workers in these trades forced both sides to seek compromise. In the late nineteenth century, interest organizations in these trades were amongst the promoters of corporatist structures at the local level, for example in various Dutch towns and cities, where in the 1890s labor unions and employers associations in construction established permanent voluntary Labor Councils (Arbeidsraden) to reconcile labor disputes (Van Veen 2013).

\section{Destroyed artisanism}

The three scenarios discussed so far challenge the standard notion that in the nineteenth century artisanism was swept away by free markets and the mechanization of production processes. The fourth scenario, "artisan destruction," demonstrates that if 
monopolies in product and labor markets in a trade were removed at an early stage, and if production processes could be easily standardized and mechanized, artisanism might rapidly disappear, even when built on long-standing guild traditions (Cf. Kocka 1984).

This was the case in the textile industry of Twente, a region in the eastern Netherlands. From the late sixteenth century, Twente's urban textile spinners and weavers were organized in guilds that, helped by the local authorities, had managed to monopolize the product and labor markets in their towns. Yet since they "had very little power over the nearby countryside", while in the countryside itself "[f]eudal ties had largely slacked", textile spinning and weaving could also develop in rural areas (Trompetter 1997, p. 144). Small farmers compensated low returns of agriculture on their sandy soils by spinning yarn from flax and weaving linen cloths that they sold to local entrepreneurs, who exported them overseas. When around 1800 guilds in The Netherlands were formally abolished, Twente entrepreneurs quickly started to concentrate textile production in one urban center, Enschede, and imported the first Spinning Jennies from the United Kingdom. With the help of the Dutch government, the Twente textile trade was gradually industrialized, wiping away hand weaving, in both towns and countryside, and destroying the traditional apprentice system by establishing weaving schools preparing large numbers of workers for labor in the new factories (Trompetter 1997).

After 1850, the mechanization of textile production transformed the small town of Enschede into a large industrial center. In the process, skilled artisans were replaced by immigrant workers who "originated from the countryside population, were used to possessing almost nothing, hardly educated, and did not form a coherent class." This entirely renewed worker population accepted the mechanization of their trade, the worsened labor conditions, and the growing social and political powers of their employers "with almost complete passivity" (Boot 1935, p. 305, our translation). Yet while industrial expansion accelerated, the number of strikes gradually increased, culminating in outright class wars in the late 1880s and 1890s. These resulted in the establishment of the first labor unions and employers' associations. In the following decades labor relations in the Twente textile industry remained volatile, with massive strikes and lock-outs and a lack of willingness on both sides to compromise and to establish conflict reconciliation structures at the local level (Van Nederveen Meerkerk et al. 2010).

The Dutch cotton trade is illustrative of a number of industries like weaving and garment production in the United Kingdom and Germany (Bythell 1969; Biernacki 1995). The early abolition of guilds and guild-like regulatory mechanisms, combined with rapid mechanization of production processes, destroyed the artisan world of masters, journeymen, and apprentices almost overnight. And since it was destroyed so quickly, functional equivalents for interest representation, conflict reconciliation, and skills-formation were slow to develop. Hence it is precisely in these trades that Crouch's idea of a "gap" in nineteenth-century interest representation and labor relations is most applicable. In these trades, new technological inventions tended to spread easily and rapidly across Europe and international competition was fierce (Hyde 1977), while large capital investments were required to enter these trades (Shin 1996). As a result, "newcomers" from outside the trade and often outside the region-traders, private capital investors, banks - replaced the former guild masters as employers, and they were unaccustomed to traditional workers' rights and labor relations (Horster 1908). With unskilled manpower entering the factories from the countryside, former 
masters and journeymen were subjected to a process of proletarianization; traditional status distinctions vanished, and with them solidarities and mechanisms to reconcile conflicts. Consequently, workers' organizations were late to arrive in these trades. In the first half of the nineteenth century, mass protests and strikes against low wages and worsening labor conditions were not uncommon, but were poorly organized and usually unsuccessful, and they did not result in the emergence of structural forms of workers' interest representation (Hanagan 1988; Mikkelsen 1996). In this situation, there was no urgency for employers to organize. Initially, employers' organizations established in these trades primarily focused on defending employers' commercial interests and lobbying local (and, occasionally, national) government. Only when labor unions emerged did employers in these trades begin to coordinate their actions against strikes and other union activities at the local level, and national employers' associations were established (Mclvor 1983; Van Waarden 1987; Herrigel 1996).

\section{New artisanism}

For various reasons, before 1800 not all trades in Western Europe had been regulated by guilds. Moreover, during the nineteenth century, new trades emerged while occupations that had been marginal now matured. The birth or growth of these trades and occupations was often closely linked to technological advancements, requiring new expert knowledge and techniques that subsequently became the domain of specific occupational groups that, with variable success, tried to limit access to their expertise.

One example of this new artisanism was the engineers in The Netherlands, whose predecessors were never organized in guilds. Its roots lay in a special service, the Department of Waterways and Public Works (Rijkswaterstaat), created in 1798 for national water management, as the Dutch Republic was transformed into a unitary state and was staffed with an Engineer Corps for Water Management (Corps Ingenieurs van den Waterstaat) (Davids 2008). Initially, Rijkswaterstaat staff members were recruited from typically artisanal backgrounds - carpenters, surveyors, millwrights - but they were soon replaced by the sons of public servants, including judges and army and naval officers, sometimes even of aristocratic origin. New institutions were introduced, like the Royal Academy for Civil Engineering (Koninklijke Akademie voor Burgerlijke Ingenieurs) set up in Delft in 1842, which would acquire full academic status in 1905. The launch of major infrastructural projects like new canals and railroad building added prestige to the engineering profession (Disco 1990).

With their education and prospects secure, engineers started to organize. In 1847, the Royal Engineers' Institute (Koninklijk Instituut van Ingenieurs, KIVI)—still today the trade's leading professional organization - was founded, followed in 1853 by the Society of Civil Engineers (Vereniging van Burgerlijke Ingenieurs, VBI). Both organizations sought to improve the position of their members and the esprit de corps among engineers; only Delft graduates were accepted as members. Of the active KIVI members in the $1850 \mathrm{~s}$, one third was employed by Rijkswaterstaat and $16 \%$ by the army; the other half worked in assorted jobs (Lintsen 1980). The VBI was, however, incapable of regulating the labor market for engineers and had to accept its members' redundancy when large infrastructural projects were terminated (Lintsen 1980). Nevertheless, in the twentieth century, Delft Academy graduates became a very influential occupational group in the Netherlands. As the state bureaucracy expanded, it became 
the purveyor of the technical ministries and even turned out cabinet ministers on a regular basis (Disco 1990).

The engineering occupation in The Netherlands exemplifies occupations in our three countries that were new in the nineteenth century or had transformed to such an extent that by 1900 they hardly resembled their predecessors - like lawyers, who benefited from national state formation, and university professors, who benefited both from technological progress and the formation of national educational systems. Over the course of the nineteenth century, they became the artisans of a new age, i.e., "professionals." In some cases, these professionals succeeded in gaining control over access to their trade in manners reminiscent of the guilds before 1800 . Like pre-1800 artisans, the new professions used their expert knowledge and techniques to erect barriers against outsiders. Controlling occupational training and establishing exclusive professional associations for the development of work standards and quality criteria, they managed to regulate their labor markets, often backed up by government legislation (MacDonald 1995).

However, around 1900, the contribution of the new professionals to emerging national political economies in the three countries became limited for at least two reasons. First, precisely because access to the professions was often controlled by the professional group and becoming a full member of the profession required prolonged training, the numbers remained limited. By 1900 the "free professions" as a percentage of the total labor force did not exceeded 5\% (see Table 3). Second, the relation between "master" and "apprentice" tended to be (and still is) paternalistic and close, so a clear employer-worker relationship failed to emerge. Even when the new professionals became employees, their exclusive skills and specialized knowledge usually provided them with a high level of autonomy vis-à-vis their employers (MacDonald 1995).

\section{New industrialism}

The sixth scenario coincides most with the standard notion of nineteenth-century industrialization. In this scenario a trade emerged virtually out of the blue, facilitated by technological innovations. The emergence of such a new trade was the product of creative entrepreneurs and/or facilitated by state sponsorship, and it resulted in the typical Marxian clash between a small caste of factory owners and a large new class of workers, flooding in from the countryside and in due course organized in large-scale industrial unions.

One such trade was the German iron and steel industry. Modern German iron foundries began in the eighteenth century, mostly in rural areas, benefiting (especially in the Ruhr and Silesia) from the Prussian state's support for proto-industry and the absence of a strong guild structure. Mining was central to the location and operation of early industrial iron and steel works, especially due to Germany's lack of a substantial railway network until the 1860 s. This led to the industry's concentration in areas of mineral deposits, even if they had very little pre-existing economic basis. Many of the important nineteenth-century Ruhr companies began as family enterprises, such as Krupp in Essen and Thyssen in Duisburg (Feldenkirchen 1982).

The 1850s saw a major expansion in iron production in the Ruhr. The Ruhr's first coke-powered furnace opened in 1849 and in the next decade coke-smelting was adopted widely. This was facilitated by the mining of hard coal and iron ore deposits in the Ruhr valley. From the 1850 s, the rapid expansion of the German railway system created a huge demand, spurring industrialization and expansion of production 
Table 3 The labor force in Germany, The Netherlands, and the United Kingdom circa 1900, employment in trades as percentage of total labor force

\begin{tabular}{|c|c|c|c|}
\hline & $\begin{array}{l}\text { Germany } \\
(1895)\end{array}$ & $\begin{array}{l}\text { Netherlands } \\
\text { (1899) }\end{array}$ & $\begin{array}{l}\text { United } \\
\text { Kingdom } \\
(1901)\end{array}$ \\
\hline Agriculture and forestry & 41.8 & 31.0 & 13.0 \\
\hline Manufacturing & 33.5 & 33.4 & 43.9 \\
\hline Bricks, pottery, glass, cement, etc. & 2.5 & 1.8 & 0.9 \\
\hline Building and contracting & 4.4 & 7.6 & 5.8 \\
\hline Chemicals and allied industries & 0.6 & 0.5 & 1.1 \\
\hline Clothing & 5.9 & 4.8 & 4.0 \\
\hline Food, drink and tobacco & 4.4 & 6.0 & 2.8 \\
\hline Gas, electricity, and water & 0.1 & 0.2 & 1.4 \\
\hline Leather industries & 0.2 & 2.1 & 1.2 \\
\hline Metal & 5.1 & 4.3 & 12.1 \\
\hline Mining and quarrying & 1.8 & 0.8 & 5.5 \\
\hline Paper, printing, and publishing & 1.2 & 1.1 & 1.7 \\
\hline Textiles & 4.2 & 2.1 & 5.9 \\
\hline Timber, furniture, etc. & 2.9 & 2.0 & 1.4 \\
\hline Services & 24.7 & 35.6 & 43.1 \\
\hline Transport and communication & 2.6 & 7.1 & 7.8 \\
\hline Insurance, banking, distributive trades, hotels, etc. & 8.4 & 10.3 & 13.9 \\
\hline Education & 1.0 & 0.8 & 1.5 \\
\hline Private domestic services & 6.7 & 10.3 & 10.6 \\
\hline Medical services & 0.5 & 0.6 & 0.6 \\
\hline Public administration and defense & 3.9 & 3.5 & 4.7 \\
\hline Free professions & 1.5 & 3.0 & 4.0 \\
\hline Total & 100.0 & 100.0 & 100.0 \\
\hline
\end{tabular}

For comparability reasons, some of the trades in the three countries have been redefined or merged

Sources: Germany: Hoffmann 1965. The Netherlands: www.volkstellingen.nl, retrieved 21 June 2015. The UK: Feinstein 1972, Tables 129-131. Table 131 presents the outcome of the 1901 census, but does not provide detailed figures for various trades within manufacturing. These have been estimated on the basis of the calculated percentages for these trades of the total figure for "manufacturing" in the 1920 census, which was the first to provide such detailed figures

(Fremdling 1977). Ruhr heavy industry became vertically integrated: mines, foundries, and factories were often constructed close together and were owned by the same company. Much of German heavy industry came to be dominated by employer cartels, like the Schienengemeinschaft, which in 1870 controlled over $75 \%$ of domestic steel sales. By the early twentiethh century, cartels were a major feature of the German industrial economy (Webb 1980).

Labor migration was a key element in the rise of the German iron and steel industries and in the allied mining sector, which from 1810 had been stimulated by Prussia (Jackson 1997). Thus the iron and steel industries in the Ruhr employed large numbers of unskilled migrant workers from nearby regions. While these unskilled migrant 
workers had low job security and were exposed to business cycles and fluctuations, skilled workers were well-paid and in high demand, and often migrated from far away. Unionization did not begin until the late nineteenth century (Crew 1979). Due to the often-huge size of the iron and steel companies and the absence of traditional labor relations, labor relations were authoritarian, with the firms often owning the housing and providing social insurance to employees and their families, and dominating the areas around their factories, foundries, and mines. Finally, effective technical education and training through factory apprenticeships were important elements of the German iron and steel industry (Crew 1979).

In the nineteenth century in the three countries we selected for our analysis, only a small minority of trades - those thriving on the real innovations of the time, like chemicals and electricity — was really entirely new (see Table 3 ). And in the end, this "newness" did not distinguish them fundamentally from those highly industrialized trades that were not so new and in which guilds had played an important role before the nineteenth century, like the trades of the "destroyed artisanism" type. In the new industrialized trades interest organizations of workers and employers were late to arrive, while labor relations were stressed and often violent. Eventually, as in the case of destroyed artisanism, this situation did not result in the emergence of corporatist structures, but in conflict reconciliation on the shop floor and in strong labor unions focusing on the national political arena for labor protection and social security legislation.

\section{From local to national citizenship rights}

After exploring six scenarios of what happened to various artisan trades under the influence of nineteenth-century economic liberalization and industrialization, we now investigate which scenarios unfolded in Germany, the United Kingdom, and The Netherlands. More specifically: What did the unfolding of specific trade scenarios mean for the construction and type(s) of national citizenship rights in these countries, and what was their role in shaping emerging national political economies?

\section{Germany: decentralized corporatism, citizenship rights largely based on occupational status}

The standard conception of German industrialization in the second half of the nineteenth century is one of rapidly emerging large-scale industrial firms, supported by state sponsorship and large universal banks. This picture of a sudden and orchestrated industrialization is only partially accurate. From the 1850 s in "poor agricultural regions, relatively free of preindustrial handicraft infrastructure and with relatively large class of property-less labor," such large-scale firms did emerge, sometimes employing thousands of workers (Herrigel 1996, p. 20). They were the result of the unfolding of the fourth (destroyed artisanism) and sixth scenarios (new industrialization). From the 1840s in sectors like textiles (e.g., in Silesia, Nuremberg, and Augsburg) and mining (e.g., in the Ruhr Valley), new entrepreneurs with access to speculative capital and technologies borrowed from early industrializers, like the United Kingdom and Belgium, set up large-scale companies from scratch, wiping out the preindustrial order almost entirely. Meanwhile, in some German regions entrepreneurs from outside set up trades largely new 
to these regions, e.g., iron and steelmaking in the Ruhr Valley, and the machinery industry in Saxony, Berlin, the Ruhr Valley, and northern seacoast harbor towns like Hamburg and Danzig. In the late nineteenth century, these entrepreneurs organized in cartels and tradespecific employers' associations, actively teaming up with the authorities of the new German Reich to combat the emerging labor movement (Herrigel 1996).

Yet in the same period, a whole range of small- and medium-sized firms developed, specializing in the production of high-quality products like metal ware and cutlery (Remscheid, Solingen), optical equipment (Württemberg), weapons (Thüringen), and special machinery (Mönchengladbach, Krefeld, and other towns on the left bank of the Rhine), to mention only a few. Out of this hotchpotch of firms, a second institutional structure emerged, which Herrigel (1996) dubbed the "decentralized industrial order". This order was composed of firms that developed more or less according to our second and third scenarios - industrialized and liberalized artisanism - out of the preindustrial guilds. In the half century following the French Period, the guilds had been more or less reinstalled in most of the German states (Länder) by means of "rules which regulated access to position in the crafts by establishing residence requirements and providing for master-dominated examinations; laws which clearly distinguished between masters, journeymen, and apprentices in terms of economic power, social standing and influence within the changing guilds; master-dominated labour market regulations; various instruments, by which both master organizations and communal authorities could try to control journeymen, their hostels and their collective actions" (Kocka 1984, p. 101). The reinstatement of guild-like regulations benefitted primarily masters. Although in most regions masters remained deprived of local political rights, due to the system of suffrage based on property qualifications (Manow 1997), they regained the local economic rights they had held before 1800, including control over local product markets and access to skills-formation (Kocka 1984). Their firms were often family-owned and remained deliberately small in order to be flexible and innovative, which was also accomplished by closely cooperating with other small firms in the same town or region. By establishing regional savings and cooperative banks (Sparkassen and Genossenschaftsbanken), often in close collaboration with local authorities, the owners of these firms pooled capital and facilitated innovation (Koselleck 1967; Bergmann 1973; Kocka 1986). In the smallest of these firms, the relationship between master and skilled workers remained very close and cooperative, signified by the fact that master and worker were often members of the same local or regional craft chamber (Innung), the direct successors of the guilds. In the somewhat bigger firms, journeymen were gradually pushed into wage labor and after 1850 organized into craft unions (Fachvereine), but labor relations continued to be accommodating (Herrigel 1993; Kocka 1984, 1986).

From the 1840 s, control over access to labor and product markets was gradually transferred from guilds and local authorities to the Länder. To protect employment, improve competitiveness of regional firms, and prevent a concentration of industry - which might stimulate the emergence of large industrialists who could challenge their authority and cause a proletarianization of the working population - the Länder authorities actively "steered" the development of these trades. Due to this regionalization of economic policies interest representation of employers also evolved along regional lines, resulting in mixed local and regional associations that lobbied local and regional government and, from 1871 via these and their national federation (the Bund der Industriellen), the political institutions of the Reich (Herrigel 1996). 
The modernization of the artisan sector produced a dichotomy between Handwerk and Industrie in the German economy still visible today. In 1907, the small and medium-sized firms in Handwerk employed about half of Germany's manufacturing workers (see Table 4; also Kocka 1986; Herrigel 1996). Handwerk workers played a decisive role in the establishment of the German labor movement in the closing decades of the nineteenth century (Kocka 1984; Nolan 1986). Artisan workers could play this important role, because workers in heavy industry were late to organize and many other sections of the German labor force were not legally allowed to engage in union activity, like domestic personnel, or were mentally or geographically too far away from the places where union activity emerged, like agrarian workers. Moreover, unlike factory workers in heavy industry, artisan workers could build on a long tradition of organization and interest representation (Kocka 1986). Many of the "modern" German labor unions established since 1860 were in fact the direct successors of the journeymen brotherhoods (Genossenschaften) and mutual insurance funds (Kassen) that had survived the French Period or had been re-established in the early nineteenth century (Hennock 2007).

From the 1860s, Handwerk workers also played a pivotal role in the establishment of the first Socialist political parties, which would eventually merge into the Social Democratic Party of Germany (Sozialdemokratische Partei Deutschlands; Kocka 1986). These socialist parties gained momentum after national political rights, in the form of suffrage for the Reichstag of the newly formed North German Confederation (Norddeutscher Bund; replaced in 1871 by the German Reich), were granted in 1867 to all males over age 25 . In the late 1870 s and the 1880 s, the parties were actively persecuted by the German authorities, culminating in Bismarck's Anti-Socialist Laws (1878). Even after these laws were lifted in the early 1890 s, national political citizenship rights of German workers would remain very limited until World War I, due to the small role of the Reichstag at the national level, and the systems of local and regional

Table 4 Percentages of the industrial working force by company size in Germany, The Netherlands, and the United Kingdom in 1907

\begin{tabular}{llll}
\hline $\begin{array}{l}\text { Number of } \\
\text { employees per company }\end{array}$ & $\begin{array}{l}\text { Germany } \\
\text { Industrie and } \\
\text { Handwerk }\end{array}$ & $\begin{array}{l}\text { The Netherlands } \\
\text { Industry }\end{array}$ & $\begin{array}{l}\text { United Kingdom } \\
\text { "Manufacturing", } \\
\text { not including mining, } \\
\text { construction, and utilities }\end{array}$ \\
\hline $1-5$ & 31.2 & 77.0 & $?$ \\
$6-10$ & 7.0 & 11.7 & $?$ \\
$11-50$ & 19.4 & 9.2 & $?$ \\
$51-200$ & 20.8 & 1.7 & $?$ \\
$201-1000$ & 16.7 & 0.3 & $?$ \\
$>1000$ & 4.9 & 0.1 & - \\
Total & 100.0 & 100.0 & $?$ \\
\hline
\end{tabular}

Sources: Germany: Hoffmann 1965, p. 212, Table 25. The Netherlands: Van der Does 1946, p. 185. The figures refer to workers in companies that were mandatory insured against disability under the Ongevallenwet1901, which in this period only covered workers in industrial companies. The categories for the Netherlands are: 1-4, 5-9, 10-49, 50-199, 200-999, and $\geq 1000$. United Kingdom: Hannah 2008, p. 63, Table 2. Unfortunately, percentages for the other categories are not available 
suffrage that continued to apply property qualifications until 1918 (Manow 1997). In this situation, Socialist labor unions and political parties had no other choice than to focus on attaining national economic and social citizenship rights for their members. The same authoritarian German state that tried to frustrate unionism in other respects, helped them-largely unintentionally - to achieve this objective. In the $1880 \mathrm{~s}$, Bismarck introduced several national social insurance schemes meant to weaken the position of Socialist unions and parties and to divert the loyalty of their members to the Reich. The schemes were largely modelled on the still-flourishing mutual insurance funds that workers had established in the first half of the century. These were to be administered by local and regional tripartite boards composed of employers' and unions' representatives and functionaries of municipalities and Länder (Hennock 2007). Once in place, labor unions successfully used their strong position in workers' communities to get their members elected to the boards; this not only enabled them to strengthen their position amongst German workers - by means of clientelism and cooptation-but also gradually expanded their influence on local, regional, and national socio-economic decision-making (Nolan 1986; Manow 1997).

Steinmetz (1993, p. 44) claims that the creation of these "proto-corporatist" structures also "laid the groundwork for the full-fledged corporatism of Weimar and adumbrated the main lines of West Germany's 'social partnership." While already around the turn of the twentieth-century, bipartite corporatist structures had institutionalized at the regional level in the industrialized and liberalized artisanal trades, multiplying collective bargaining agreements, after World War I collective bargaining also became the standard in largescale industries like metal and machinery construction, albeit at the sectoral level. After World War II, labor unions and employers' associations would also start closing national collective bargaining agreements, thus finalizing the complex German corporatist political economy, composed of regional, national, and sectoral arenas (Herrigel 1996).

\section{The United Kingdom: no corporatism, citizenship rights largely based on citizenship status}

As the first nation in history to industrialize the United Kingdom could build on relatively favorable socio-economic and socio-political structures, in both rural and urban areas. From the fifteenth century, in subsequent waves of "enclosures," landowners had merged small landholdings into larger and more productive and profitable lease holds on a large scale, also swallowing up the commons which had been available for peasants to graze their cattle. As a result, by the mid-eighteenth century not only large numbers of unemployed and impoverished agricultural workers came available for production in the first factories - a "rationalized" British agricultural sector could also feed them (Mathias 2001). Already in the course of the eighteenth century, in most cities and towns many guilds had become ineffective, largely due to the inability or unwillingness of authorities and courts to uphold the charters and regulations that had underpinned their powers, especially the Statute of Artificers (1563), which had regulated wages, movement and training of artisans, and the numbers and prices of their products (Eisenberg 1991).

The disintegration of the guild system enabled newcomers to start new workshops in towns and villages, facilitating the spread of a proto-industrial putting-out system, which from the mid-eighteenth century transformed into the first mechanized factories, 
starting with cotton production in Lancashire. In subsequent decades, trades like coalmining (in the Midlands, Northumberland, Lancashire, Yorkshire, and parts of Scotland and Wales) and iron and steel production began to benefit from the orders of cotton manufacturers or their experimentation in mechanization and rationalization, and the trades themselves took the first steps toward industrialization (Mathias 2001). Hence the first round of industrialization in the United Kingdom between c. 1750 and the early nineteenth century was characterized by the emergence of several near-new trades, like cotton, or the complete transformation of trades that had so far been relatively marginal, like coal, iron, and steel (new industrialism). Almost by definition, this was the work of adventurous entrepreneurs "divorced from older traditions of urban life and paternalism," who ploughed the profits of their early enterprises back into their businesses or, when large investments in machines were required, borrowed the money from big landowners, merchants, financiers, and other sections of the traditional British elite. Unlike aristocracies in most other European countries, this elite group was far from hostile to the emerging industries. In the early nineteenth century, in close collaboration with the new industrial entrepreneurs organized into the Whig party, it successfully pushed Parliament to lift all sorts of trade tariffs and legal barriers for further capitalist and industrial development (Hobsbawm 1994, quote p. 231).

The liberalization of the British economy caused a second wave of industrialization, which transformed a whole range of existing artisanal trades in consumer goods production, such as food and drink, construction, shoemaking, carpentry, pottery and textiles other than cotton, like linen and silk (Prothero 1979; Calhoun 1983). In these trades, a specific form of the destroyed artisanism scenario unfolded. As in Germany, industrialization in these trades resulted in the emergence of small- and medium-sized firms that superficially resembled the modernized late-nineteenth century German artisanal workshops. Yet, unlike Germany, in Britain, industrialization in these trades did not take place within a traditional order. With artisanal traditions severely weakened before industrialization and prevailing socio-economic and socio-political conditions that made the revival of those traditions very unlikely, it was predominantly newcomers - "small, newlyestablished master[s], undercutting in price, overworking labour, breaking apprenticeship agreements"-who modernized production processes in these trades, in the process simply outcompeting existing workshops that stuck with traditional production methods (Mathias 2001, p. 365; Prothero 1979). As in Germany, English industrial firms in these trades remained relatively small throughout the nineteenth century, but for different reasons. In Germany, this was the result of strategies of masters trying to keep their firms flexible and innovative and of local and regional government policies discouraging the development of big industry. In the United Kingdom, workshops were forced "within structures dominated by large capital, through intensive sub-division of tasks and subcontracting on the one hand, and dependence on large capital for credit and orders on the other" (Crossick 1997, p. 27).

During the first half of the nineteenth-century, traditional workshops in only a small minority of trades survived by moving into niche markets of high-quality products or specializing in made-to-measure products. In most other trades, traditional production methods and labor relations gradually disappeared, blurring the lines between (former) masters and journeymen, who increasingly stood on the same side when protesting the infringement of their "traditional rights" (Prothero 1979; Chase 2000). By this time, local citizenship rights of artisans and workers had been undermined almost everywhere, 
without being replaced by a new national citizenship. The repeal of the Statute of Artificers by Parliament in 1813 only formalized a situation in which guild-related local economic and social rights of artisans and workers had already become ineffective in most regions. The local political rights that certain categories of craftsmen and laborers still enjoyed in some boroughs and counties were nullified by the First Reform Act of 1832, which confined the vote to men of property (Daunton 2001).

With the divide between masters and journeymen dissolving, traditional forms of interest organization also lost their relevance in these trades, without other forms taking their place for a long time. Until the 1840s, employer-encouraged active repression by local and national government prevented the development of new workers' organizations. The only form of working-class association that was permitted, and even encouraged by the authorities were "friendly societies," voluntary mutual sickness and funeral insurance funds of workers that were usually not restricted to any specific trade (Hennock 2007).

Only in the 1850s and 1860s was the spell on effective workers' organization broken by a combination of rapid changes, one being the changing character and outlook of the workers' population itself. By that time the "reactionary" protests of master and journeymen aimed at restoring "traditional rights" had waned, signifying that workers "no longer had strong 'radical roots' in preindustrial social organization" (Calhoun 1983, p. 491). Meanwhile unionism in the industrialized trades, like textiles and mining - characterized by large plants and ditto worker forces (see Tables 3 and 4) - finally experienced their breakthrough. Various types of workers' organizations merged into strong "New Model" unions consolidated at the trade level. From the 1860s, these collaborated closely in the national Trade Union Congress (TUC), which in subsequent decades would grow into a formidable interest organization (Pelling 1987; Chase 2000). The advancement of modern unionism in Britain was also facilitated by the authorities, which ceased their repressive anti-union policies and legalized workers' organizations in 1872 (Calhoun 1983). This policy shift was part of a broader attempt to integrate the lower and middle classes into the capitalist British nation. A series of franchise expansions in 1867-1884 gave the vote, both at the local and the national level, to about $60 \%$ of male workers (Price 1990; for the development of citizenship rights in the United Kingdom, see Table 5).

The coincidenceof the rise of modern unionism and the - compared to Germany (de facto) and The Netherlands (formally) - early granting of national political citizenship shaped the character of British unions. Early access to, and trust in, democratic institutions stimulated a reformist, instead of revolutionary, outlook in the trade union movement (Price 1990). From the 1870s, the unions and the TUC actively pushed and financed the election of union Members of Parliament (MPs), who until World War I functioned within the Liberal Party. The Liberal Party, more dependent on the working-class vote, when in government enacted several Factory and Workshop Acts (1870-1901) that protected child and female labor and regulated safety on the shop floor (Hennock 2007).

With national political citizenship secured for most of their members, unions could concentrate on their struggles with industrial employers. While early in the century, industrial employers had been loosely organized into clubs defending the commercial interests of their members in specific trades, from the 1840 s - in reaction to growing workers' protests and strikes - these clubs transformed into strike-breaking organizations, which at the local and regional levels coordinated lock-outs and insured their members against their financial consequences. In the last two decades of the nineteenth century, British industrial employers gradually shifted their strategy toward acceptance 


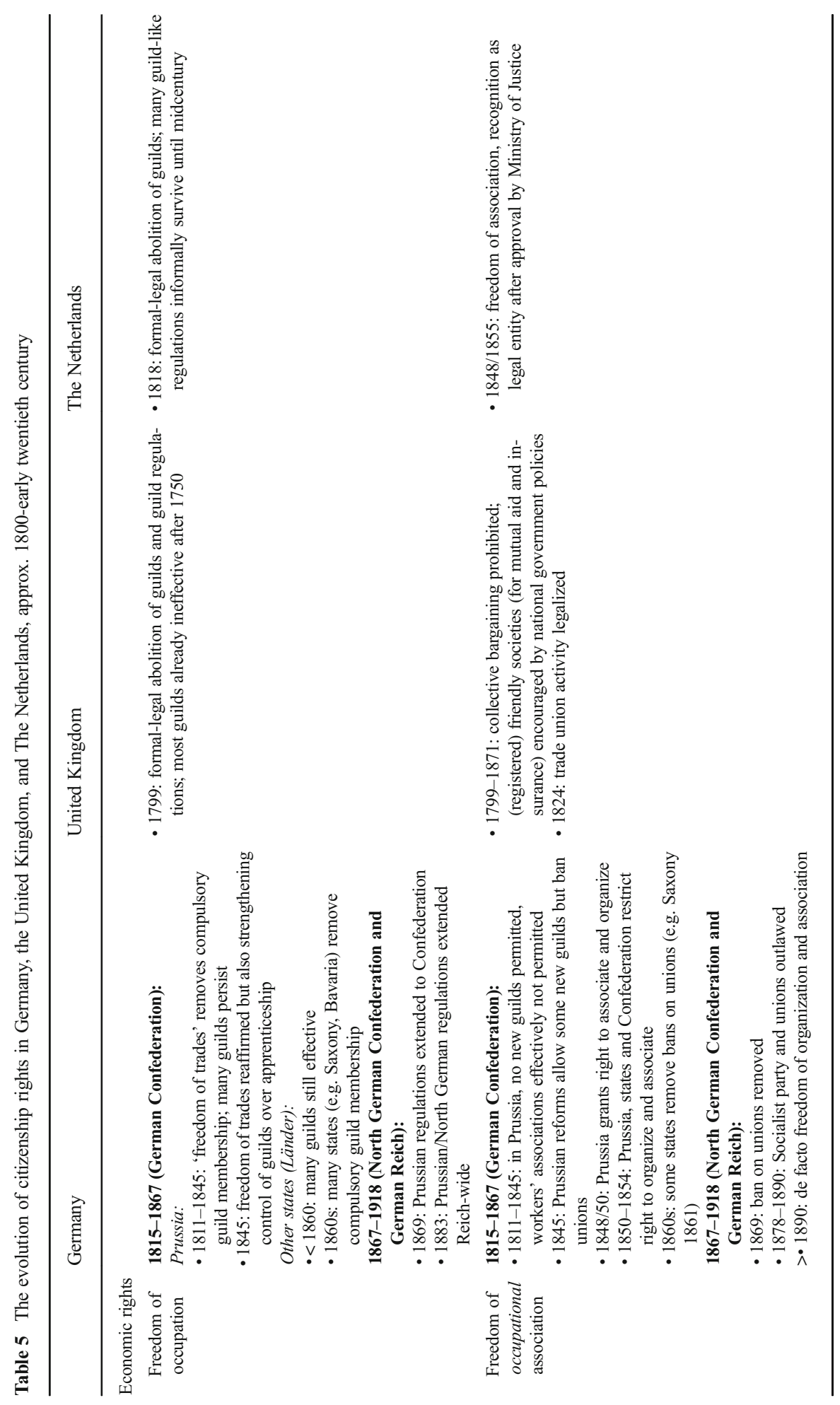




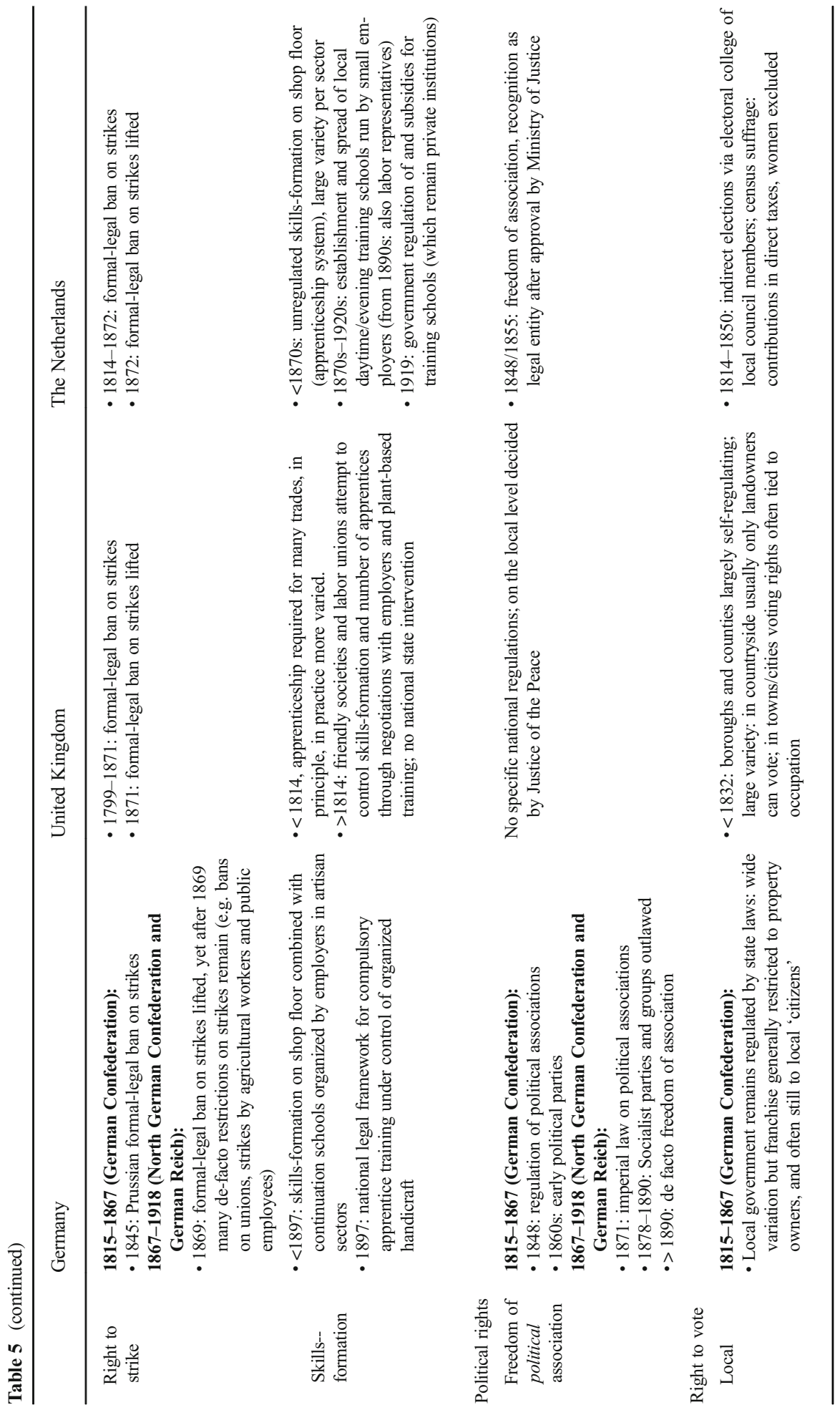




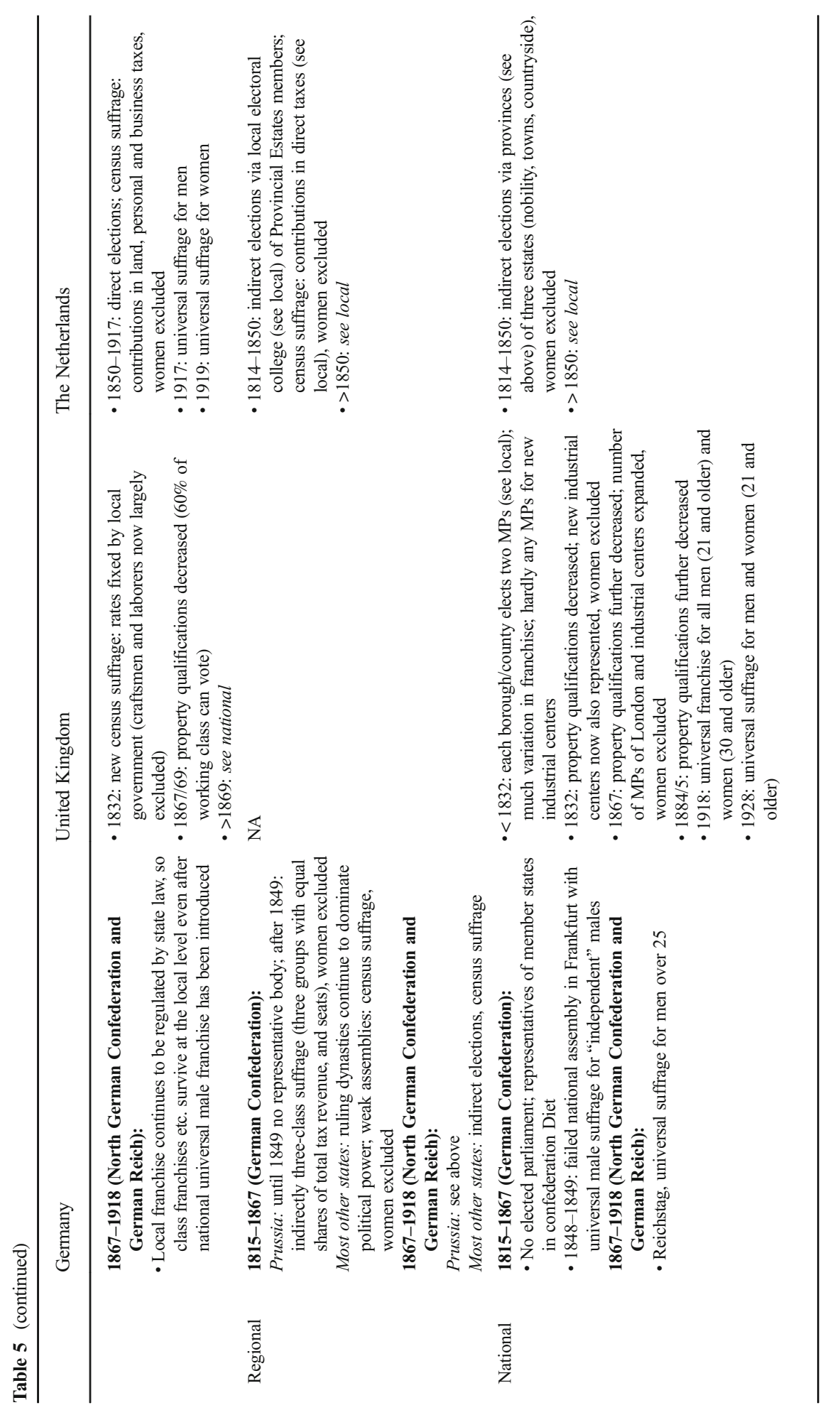




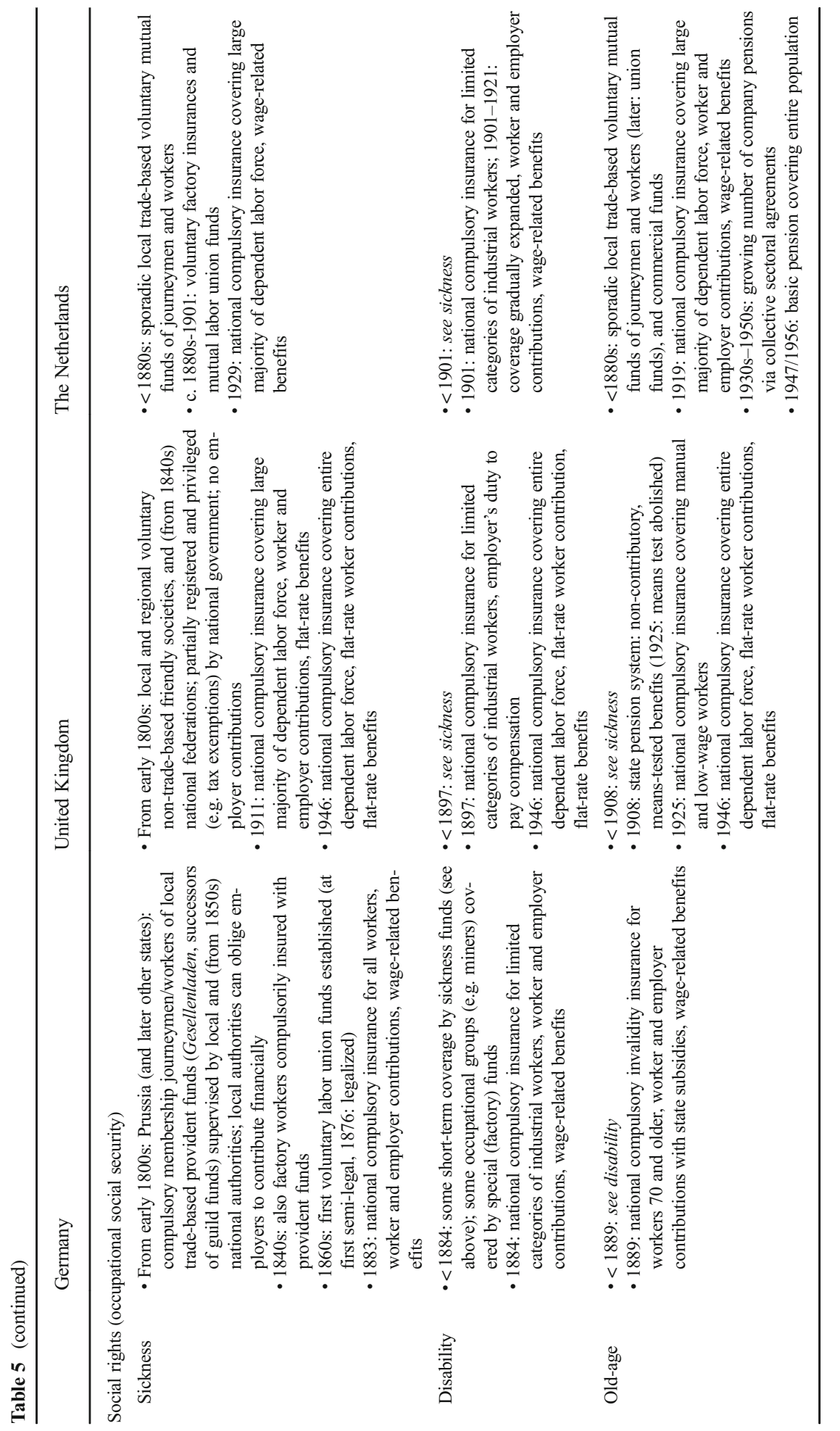




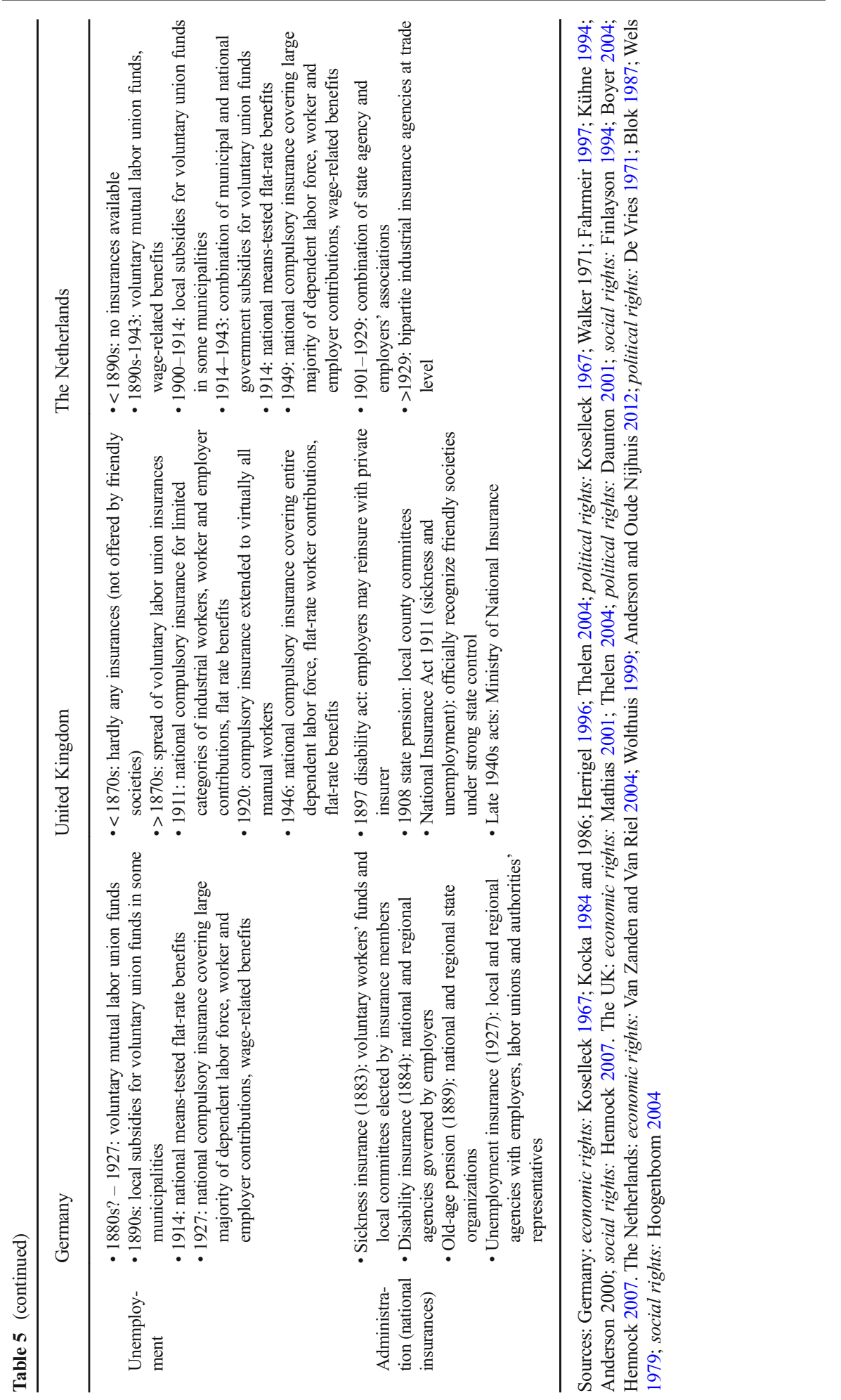


and recognition of trade unions. Part of this was the development of arbitration procedures on the shop floor and collective bargaining at the trade level (Mclvor 1983; Adams 1997).

With the shop floor and sectoral negotiation platforms emerging as the place where unions negotiated wages, perquisites, and labor conditions with employers' associations, from the turn of the century unions (via their Liberal Party MPs and later via the newly-formed Labour Party) propagated the establishment of national social insurance schemes. In 1906, a Liberal government, supported by the Labour Party, introduced national health insurance and national insurance schemes against sickness and unemployment, followed two years later by a state pension scheme. At first these schemes covered only parts of the British population, but during World War I and during the interwar years these gradually expanded, taking shape as the "Beveridgian" welfare state that would be consolidated after World War II, with flat-rate and means-tested benefits provided by state agencies to all eligible adult citizens (Hennock 2007).

\section{The Netherlands: centralized corporatism and citizenship rights based on occupational and citizenship status}

Whereas nineteenth-century economic and political developments in Germany resulted in the emergence of national citizenship rights largely based on occupational status and in the United Kingdom on citizenship per se (i.e., membership in the national "community"), in The Netherlands they produced a combination of both. Also in the development of a national political economy, the Dutch case shows elements of both the British and German experiences. The mixed character of national citizenship rights and the national political economy can be largely explained by the dual structure of the Dutch economy after 1850 .

This dual economic structure was partially a historical legacy of the Dutch Republic of the Seven United Provinces (1581-1795). In the Republic, international trade and finance had been among the dominating sectors, a position it still held by the late nineteenth century (De Vries and Van der Woude 1997). In addition, in the Republic, as an offshoot of international trade, especially with the Baltic region and the Dutch East Indies, processing industries had emerged in and around Amsterdam and Rotterdam. Already in the seventeenth century, mechanical techniques, often driven by windmills, were used to process coffee, cacao, sugar, paper, and various oil types. In the early nineteenth century, these were among the first Dutch trades to introduce steam machines and to scale up their production processes (Davids 2008).

Next to these large sectors, the economy of the Dutch Republic was characterized by small artisan workshops run by masters who were usually organized into guilds. Access to the guilds was usually dependent on local citizenship status, which, next to economic rights, could also give access to political rights (electing city magistrates) and social rights (membership of mutual social insurance funds) (Prak et al. 2006). National citizenship was introduced under French occupation but offered very few rights compared to the local citizenship it replaced (Prak 1997). The guilds were formally abolished and not reinstalled when the Dutch state became independent again in 1813 . The result was that the vast majority of the population, including most artisans and workers, was deprived of local political citizenship rights (Van Genabeek 1994), while when the French left national voting rights were restricted to a small wealthy elite (Blok 1987) (for an overview of the development of citizenship rights in the Netherlands, see 
Table 5). Yet, due to economic stagnation and mercantile economic policies of both local and national government, many guild-like regulatory mechanisms survived informally at least until the $1850 \mathrm{~s}$. This allowed artisans in many trades to maintain part of their traditional local economic rights, like control over product and labor markets and skills-formation, often by means of local cartels tolerated by the local authorities (Van Zanden and Van Riel 2004). In this period about $80 \%$ of all Dutch manufacturing firms were still small workshops of manual production by masters and their journeymen, predominantly supplying the local market (Anderson and Oude Nijhuis 2012).

Until 1850, only in a few trades did the formal abolition of guild regulation stimulate the introduction of new mechanized techniques and the establishment of large factories (destroyed artisanism): production of textiles (Twente), glass and ceramics (the southern city of Maastricht), sugar refinery (West Brabant), and shipbuilding (predominantly in and around Amsterdam and Rotterdam). When, in the 1860s and 1870s, the Dutch economy was finally liberalized through the abolition of local, regional, and national tolls and tariffs, various new large-scale industries emerged (new industrialism), for instance in chemicals (Rotterdam area), machine building (Amsterdam and Rotterdam) and mining (the southern Limburg province) (Van Zanden and Van Riel 2004). The owners of these new industries were soon incorporated into the old socio-economic elite of bankers, insurers, and traders, which gave them easy access to Parliament and national government, and which for a long time made their formal organization unnecessary. Only when labor unions also gained access to the political arena in The Hague around 1900, did they establish the Association of Dutch Employers (Vereeniging van Nederlandsche Werkgevers), which until the 1920s would remain the most powerful socio-economic pressure group in the Netherlands (Hoogenboom 2004).

Meanwhile the liberalization of the Dutch economy after 1860 not only led to the emergence of new large-scale industries, but also - as in Germany - to a transformation and limited industrialization of existing artisanal trades like printing, construction, clothing, and shoemaking (industrialized artisanism and liberalized artisanism). Yet this process took much more time to unfold than in Germany, due to the late availability of new technologies and to institutional factors such as low wages and high coal prices resulting from the absence of large-scale coal mines and a comprehensive railroad system until the 1890s (Van Zanden and Van Riel 2004). In 1907, almost 90\% of the total number of industrial firms still had 10 or fewer workers (See Table 4), while these small companies still employed more than three-quarters of all Dutch manufacturing workers. After 1900, in most manufacturing sectors the average number of workers per employer would only increase slowly, if at all (Van Van Gerwen and Seegers 2003).

The gradual character of change had at least two consequences, which influenced future Dutch national political economy. First, traditional labor relations between employers and workers in the artisanal trades changed slowly, preserving the small social divide between employers and workers as well as relatively harmonious labor relations (e.g., Van der Ven 1953; Hoogenboom 2004). In the 1890s, employers and workers from the artisanal trades were the driving forces behind the first attempts to establish local corporatist structures (Van Van Veen 2013). Second, the gradual transformation and industrialization in these trades also caused interest representation of employers - and of workers (see below) - to develop slowly. Because of the size of their firms and their own social status, employers in these trades had little access to the national political arena. Only when, from the late 1880 s, local and national voting 
rights were gradually extended, employers in these trades became a significant political factor, especially in the emerging Protestant and Roman Catholic political parties. After 1900 they also established their own interest organizations, many with a religious affiliation (Hoogenboom 2004).

The dual character of the Dutch economic structure and the slow transformation of the artisanal sector were also reflected in workers' interest representation. Abolition of the guilds in the early nineteenth century had deprived journeymen of local political citizenship rights, but the stagnant character of the economy and mercantile economic policies had preserved many of their traditional economic (e.g., limited access to skills-formation for outsiders) and social rights (e.g., membership in exclusive social insurance funds). After the codification of the national right of association in 1855, craft unions became more numerous, mostly in artisanal crafts like printing, construction, and gold- and silversmithing. Unlike their predecessors, these new unions acted as defenders of the "traditional rights" of their members in situations where competition on product and labor markets intensified due to the post-1860 liberalization of the Dutch economy. In the 1870 s these craft unions were also the first to establish national unions and, subsequently national federations of national craft unions in various trades (Hueting et al. 1983).

During the economic depression of the 1880 s workers in the new industries also started to mobilize, after decades of passivity, resulting in the establishment of new industrial unions. In the 1890s this "modern" labor union movement also produced the first Marxist and Social-Democratic political parties, whose main demands were universal suffrage, national labor legislation, and the creation of state-run social insurance schemes. In the late 1890 s and 1900 s, provoked by large-scale strikes and public demonstrations organized by these unions and political parties, the Liberal majority in Parliament - which had close links to the interest organizations of heavy industry - reacted by extending the vote, introducing the first labor legislation, and creating some social insurance against the risks of occupational disability and old age, administered by state-run agencies (Hoogenboom 2004).

From the turn of the century, labor unionism in The Netherlands was fundamentally transformed under the influence of the process of "pillarization" that between 1900 and 1970 compartmentalized the Dutch population into segments or "pillars" according to different religions or ideologies, each with its own political parties, labor unions, employers' associations, periodicals, broadcasting associations, housing estates, and all sorts of welfare and leisure organizations (Blom 2000). In the 1900s and 1910s, as part of this process, craft and industrial unions were forced to join national Roman Catholic, Orthodox Protestants, or Social Democratic union federations. This reshuffling of affiliations forced craft unions to modernize their organization, while pacifying large parts of the once-militant industrial unions, even in the Social Democratic pillar (Hoogenboom 2004).

When in 1917 and 1919 universal suffrage for adult males and women was introduced, the Roman Catholic and Protestant political parties together succeeded in capturing a majority in Parliament and a dominant position in the national government, which they would retain long after World War II. This strong political position enabled confessional employers' associations and labor unions - which represented, more than the Social Democratic unions, workers from the liberalized artisanal trades (Hoogenboom 2004) - to leave their mark on the emerging national political economy. From the 1920 s, legislation was introduced that made national socio-economic decision-making the domain of tripartite institutions composed of government representatives, national 
employers' associations, and labor union federations. At the level of individual trades, this system was backed up by bipartite corporatist institutions, where the branches of national employers' associations and labor union federations negotiated over wages and perquisites. Topping the schemes created by Liberal governments in the early 1900s, and partially replacing them, Roman Catholic and Protestant cabinet coalitions-supported by confessional labor unions and employers - subsequently introduced a series of Bismarckian insurances (against risks of sickness, unemployment, and parenthood), with wage-related benefits administered by the branches of national employers' associations and labor union federations collectively. This corporatist administrative system would remain in force until 2002 (Van Waarden 2002).

\section{Conclusion and discussion}

Not so very long ago, the birth of modern society looked like a straightforward story: two simultaneous revolutions created a clear break with the past, delivering the industrialized economy and democratic nation-states to the world. Historians and social scientists have come to acknowledge the flaws in this argument, realizing that the rupture was not so clear-cut and that many Old Regime traits survived long into the "modern" era. Alternative analytical narratives have been handicapped by taking for granted the national context whose emergence they wanted to explain. We have traced the emergence of the new national political economies of the late nineteenth and early twentieth centuries on the disaggregated levels of trades and localities, and we have demonstrated under what circumstances continuities from the Old Regime could be incorporated into the new institutional structures. This very much depended, we showed above, on the continued vitality of on the one hand crafts and, on the other hand, local and regional authorities within the national framework. Where both were lacking, as in England, the standard narrative of "modernization theory" continues to apply. Where both were strong, as in Germany, a corporatist governance structure was likely to emerge. When the two were balanced, as in The Netherlands, a double structure emerged.

We showed how early forms of citizenship contributed to the formation of twentiethcentury political economies in Germany, the Netherlands, and the United Kingdom by investigating the development of various trades throughout the nineteenth century. To enable the investigation of persistence, we distinguished six scenarios of what might have happened to these pre-industrial crafts during the transition to an industrial economy. These scenarios were discussed and illustrated with concrete histories of trades and industries, and the contours were sketched of the sort of labor relations and regulatory mechanisms emerging for each type of trade. Next we established which scenarios were dominant in each of the three countries and how the political economies they produced interacted with the development of national political structures, resulting in national political economies and the distribution of national economic, political, and social citizenship rights.

Based on the analysis of the three countries we selected for our analysis, we conclude that the claims put forward in the literature about the importance of guild traditions in the formation of national political economies are only partially correct. First, we showed that in the three countries the formal abolition of guilds did not automatically mean the end of the old regulatory mechanisms. In practice, artisans often remained capable of regulating access to their trade and skills-formation far into the nineteenth century. Here our analysis 
demonstrates the fruitfulness of an approach that not only takes into account the evolution of formal economic and political institutions (see, for example, Crouch 1986, 1993, and Cusack et al. 2007), but also analyzes economic developments (cf. Kocka 1984 1986; Breuilly 1985; Herrigel 1993 1996; Crossick 1997), as we have applied here. By analyzing various types of trades - each with its own institutional and technological characteristics we can better understand how and why guild traditions survived in some trades and not in others, and how and whether they could be scaled-up from the local to the national level.

Second, by focusing on trades, rather than on the national political economy, our analysis demonstrates that in the three countries we selected for our analysis a wide variety of trades - some in which guild traditions survived, others in which these traditions had never existed or were destroyed in the nineteenth century-existed side-by-side. In the end, decisive in the formation of national political economies and citizenship rights were not some general national patterns, as for example Crouch (Crouch 1986, 1993) claims, but which of these trades came to dominate the development of national political economies by the end of the nineteenth century.

Third, in analytical terms, this article demonstrates that the creation of national political economy institutions by the end of the nineteenth and the early twentieth centuries was not necessarily a story of "power resources", as many neo-institutional authors (EspingAndersen 1990; Pierson 2000; Mahoney 2000; Thelen 2004) claim-i.e., a story of political actors and social movements struggling over whose blueprint for a national political economy was to be implemented. Whether the construction of a national political economy was an open fight depended on the availability of an existing institutional "path" and how that might affect the course of national political economy and citizenship formation. Where such a path was well developed and had adapted to new circumstances (like in our industrialized artisanism and liberalized artisanism scenarios), as in Germany, it could deeply influence the national political economy institutions that were taking shape by the end of the nineteenth and the early twentieth centuries. Where such a path was available but new industrial forces were equally strong, as in The Netherlands, this resulted in a national economy combining "premodern" and "modern" features. And where no such path was available or had been destroyed at an early stage, as in the United Kingdom, the construction of a national political economy was indeed an open fight and a national political economy could be built almost from scratch, resulting in the industrialized economy and the democratic nation-state that we know from the standard version of "modernization theory."

Open Access This article is distributed under the terms of the Creative Commons Attribution 4.0 International License (http://creativecommons.org/licenses/by/4.0/), which permits unrestricted use, distribution, and reproduction in any medium, provided you give appropriate credit to the original author(s) and the source, provide a link to the Creative Commons license, and indicate if changes were made.

\section{References}

Adams, T. (1997). Market and institutional forces in industrial relations: The development of national collective bargaining, 1910-1920. Economic History Review, 50(3), 506-530.

Anderson, K., \& Oude Nijhuis, D. (2012). The long road to collective skill formation in the Netherlands. In M. R. Busemeyer \& C. Trampusch (Eds.), The political economy of collective skill formation (pp. 101-125). Oxford: Oxford University Press.

Beier, G. (1968). Schwarze Kunst und Klassenkampf. Geschichte der Industriegewerkschaft Druck und Papier und ihrer Vorläufer seit dem Beginn der modernen Arbeiterbewegung. Band I, 1830-1890. Frankfurt-amMain: Europäischen Verlagsanstalt. 
Bergmann, J. (1973). Das Berliner Handwerk in den Frühphasen der Industrialisierung. Berlin: Colloquium Verlag. Biernacki, R. (1995). The fabrication of labor. Germany \& Britain, 1640-1914. Berkeley: University of California Press.

Blok, L. (1987). Stemmen en kiezen: Het kiesstelsel in Nederland in de periode 1814-1850. Groningen: Wolters.

Blom, J. C. H. (2000). Pillarisation in perspective. West European Politics, 23, 153-164.

Boix, C. (1999). Setting the rules of the game: The choice of electoral systems in advanced democracies. The American Political Science Review, 93(3), 609-624.

Boot, J. A. P. G. (1935). De Twentsche katoennijverheid 1830-1873. Amsterdam: H.J. Paris.

Boyer, G. R. (2004). The evolution of unemployment relief in Great Britain. The Journal of Interdisciplinary History, 34(3), 393-433.

Brantz, D. (2003). Slaughter in the city: The establishment of public abbatoirs in Paris and Berlin, 1780-1914. Dissertation University of Chicago.

Breuilly, J. (1985). Artisan economy, artisan politics, artisan ideology: the artisan contribution to the 19th century European labour movement. In C. Emsley \& J. Walvin (Eds.), Artisans, peasants, and proletarians, 1760-1860: Essays presented to Gwyn A. Williams (pp. 187-225). London: Croom Helm.

Bythell, D. (1969). The handloom weavers. A study in the English cotton industry during the Industrial Revolution. Cambridge: Cambridge University Press.

Calhoun, C. (1983). The roots of radicalism: Tradition, the public sphere, and early nineteenth-century social movements. Theory and Society, 12(4), 485-504.

Chase, M. (2000). Early Trade Unionism: Fraternity, Skill, and the Politics of Labour. Ashgate: Brookfield.

Crew, D. (1979). Town in the Ruhr: A social history of Bochum, 1860-1914. New York: Columbia University Press.

Crossick, G. (1997). Past masters: In search of the artisan in European history. In G. Crossick (Ed.), The artisan and the European town, 1500-1900 (pp. 1-40). Aldershot/Brookfield: Scolar Press.

Crouch, C. (1986). Sharing public space: States and organized interests in Western Europe. In J. A. Hall (Ed.), States in history (pp. 177-210). Oxford: Basil Blackwell.

Crouch, C. (1993). Industrial relations and European state traditions. Oxford: Oxford University Press.

Crouch, C. (2001). Welfare state regimes and industrial relations systems: The questionable role of path dependency theory. In B. Ebbinghaus \& P. Manow (Eds.), Comparing welfare capitalism: Social policy and political economy in Europe, Japan and the USA (pp. 105-124). London: Routledge.

Crouch, C. (2005). Capitalist diversity and change. Recombinant governance and institutional entrepreneurs. Oxford: Oxford University Press.

Cusack, T. R., Iversen, T., \& Soskice, D. (2007). Economic interests and the origins of electoral systems. The American Political Science Review, 101(3), 373-391.

Daunton, M. (2001). Introduction. In idem, The Cambridge urban history of Britain, Vol. 3, 1840-1950 (pp. 1-56). Cambridge: Cambridge University Press.

Davids, K. (2008). The rise and decline of Dutch technological leadership: Technology, economy and culture in the Netherlands, 1350-1800. Leiden: Brill.

De Vries, J. (1971). Het censuskiesrecht en de welvaart in Nederland 1850-1917. Economisch-ensocialhistorisch jaarboek, 34, 178-231.

De Vries, J., \& Van der Woude, A. (1997). The first modern economy: Success, failure, and perseverance of the Dutch economy, 1500-1815. Cambridge: Cambridge University Press.

Disco, C. (1990). Made in Delft. Professional engineering in the Netherlands, 1880-1940. Dissertation, University of Amsterdam.

Eisenberg, C. (1991). Artisans' socialization at work: Workshop life in early nineteenth-century England and Germany. Journal of Social History, 24(3), 507-520.

Epstein, S. A. (1991). Wage labor and guilds in medieval Europe. Chapel Hill: University of North Carolina Press.

Epstein, S. R. (1998). Craft guilds, apprenticeship and technological change in pre-modern Europe. Journal of Economic History, 53, 684-713.

Esping-Andersen, G. (1990). The three worlds of welfare capitalism. Cambridge: Polity Press.

Fahrmeir, A. K. (1997). Nineteenth-century German citizenships: A reconsideration. The Historical Journal, 40, 721-752.

Feinstein, C. H. (1972). National income, expenditure and output of the United Kingdom, 1855-1965. Cambridge: Cambridge University Press.

Feldenkirchen, W. (1982). Die Eisen- und Stahlindustrie des Ruhrgebiets, 1879-1914. Wachstum, Finanzierung und Struktur ihrer Grossunternehmen. Wiesbaden: Franz Steiner Verlag.

Finlayson, G. (1994). Citizen, state and social welfare in Britain 1830-1990. Oxford: Oxford University Press.

Fremdling, R. (1977). Railroads \& German economic growth: A leading sector analysis with a comparison to the United States and Great Britain. Journal of Economic History, 37(3), 583-604. 
Grady, K. (2000). The cattle and meat trades in Leeds, 1780-1900. Northern History, 37(1), 133-155.

Guinnane, T. W., \& Timothy, W. (2001). Cooperatives as information machines: German rural cooperatives, 1883-1914. Journal of Economic History, 61, 366-389.

Hall, P. A., \& Soskice, D. (Eds.). (2001). Varieties of capitalism: The institutional foundations of comparative advantage. Oxford: Oxford University Press.

Hanagan, M. (1988). Solidary logics. Introduction. Theory and Society, 17, 309-327.

Hannah, L. (2008). Logistics, Market Size, and Giant Plants in the Early Twentieth Century: A Global View. The Journal of Economic History, 68(1), 46-79.

Hennock, E. P. (2007). The origin of the welfare state in England and Germany, 1850-1914: Social policies compared. Cambridge: Cambridge University Press.

Herrigel, G. (1993). Identity and institutions: The social construction of trade unions in nineteenth-century Germany and the United States. Studies in American Political Development, 7, 371-394.

Herrigel, G. (1996). Industrial constructions: The sources of German industrial power. New York: Cambridge University Press.

Hobsbawm, E. (1994). The Age of Revolution: 1789-1848. London: Little, Brown \& Co

Hofmeester, K. (2004). Jewish workers and the labour movement: A comparative study of Amsterdam, London and Paris, 1870-1914. Aldershot: Ashgate.

Hoffmann W.G. (1965). Das Wachstum der deutschen Wirtschaft seit der Mitte des 19. Jahrhunderts. Berlin, Heidelberg: Springer-Verlag.

Hoogenboom, M. (2004). Standenstrijd en zekerheid. Een geschiedenis van oude orde en sociale zekerheid in Nederland. Amsterdam: Boom.

Horster, P. (1908). Die Entwicklung der Sächsischen Gewerbeverfassung, 1780-1861. Crefeld: Wilhelm Greven

Hueting, E., De Jong, E. F., \& Neij, R. (1983). Naar groter eenheid. De geschiedenis van het Nederlands Verbond van Vakverenigingen 1906-1981. Amsterdam: Van Gennep.

Hyde, C. H. (1977). Technological change and the British iron industry. Princeton: Princeton University Press.

Jackson, J. H. (1997). Migration and urbanization in the Ruhr Valley, 1821-1914. Atlantic Highlands, NJ: Humanities Press.

Jones, P. E. (1976). The butchers of London. London: Secker and Warburg.

Jones, R. H. (1987). Technology, transaction costs, and the transition to factory production in the British silk industry, 1700-1870. Journal of Economic History, 47, 75-76.

Katzenstein, P. (1985). Small states in world markets. Ithaca: Cornell University Press.

Kluge, A. (2007). Die Zünfte. Stuttgart: Franz Steiner.

Knotter, A. (1984). De Amsterdamse bouwnijverheid in de 19ee eeuw tot ca. 1870: Loonstarheid en trekarbeid op een dubbele arbeidsmarkt. Tijdschrift voor Sociale Geschiedenis, 10, 123-154.

Knotter, A. (1993). Van 'defensieve standsreflex' tot 'verkoopkartel van arbeidskracht'. Tijdschrift voor Sociale Geschiedenis, 19, 68-93.

Kocka, J. (1984). Craft traditions and the labour movement in nineteenth-century Germany. In P. Thane, G. Crossick, \& R. Floud (Eds.), The power of the past. Essays for Eric Hobsbawm (pp. 95-117). Cambridge: Cambridge University Press.

Kocka, J. (1986). Problems of working-class formation in Germany: The early years, 1800-1875. In I. Katznelson \& A. R. Zolberg (Eds.), Working-class formation. Nineteenth century patterns in Western Europe and the United States (pp. 279-351). Princeton: Princeton University Press.

Kocka, J. (1990). Arbeitsverhältnisse und Arbeiterexistenzen. Grundlagen der Klassenbildung im 19 Jahrhundert. Bonn: Verlag J.H.W. Dietz Nachf.

Koselleck, R. (1967). Preußen zwischen Reform und Revolution. Allgemeines Landrecht, Verwaltung und soziale Bewegung von 1791 bis 1848. Stuttgart: Klett-Cotta.

Kühne, T. (1994). Dreiklassenwahlrecht und Wahlkultur in Preußen, 1867-1914: Landtagswahlen zwischen korporativer Tradition und politischem Massenmarkt. Düsseldorf: Droste Verlag.

Leisink, P., \& Leisink, H. (1994). t Schild der solidariteit. Een sociaalhistorische studie van 125 jaar grafische arbeidsverhoudingen en vakbondswerk. Amsterdam: FNV Pers/Druk en Papier FNV.

Lenger, F. (1991). Beyond exceptionalism. Notes on the artisanal phase of the labour movement in France, England, Germany and the United States. International Review of Social History, 36(1), 1-23.

Lintsen, H. (1980). Ingenieurs in Nederland in de negentiende eeuw. Een streven naar erkenning en macht. The Hague: Nijhoff.

MacDonald, K. M. (1995). The sociology of the professions. London: SAGE.

MacLachlan, I. (2004). The greatest and most offensive nuisance that ever disgraced the capital of a Kingdom: The slaughterhouses and shambles of modern Edinburgh. Review of Scottish Culture, 17, 57-71. 
MacLachlan, I. (2007). A bloody offal nuisance. The persistence of private slaughter-houses in nineteenthcentury London. Urban History, 34(2), 227-254.

Mahoney, J. (2000). Path dependency in historical sociology. Theory and Society, 29, 507-548.

Manow, P. (1997). Social insurance and the German political economy. Cologne: MPIfG Discussion Paper 97/2.

Marshall, T. H. (1992/1950). Citizenship and social class. In T. H. Marshall \& T. Bottomore (Eds.), Citizenship and social class (pp. 3-51). London: Pluto Press.

Mathias, P. (2001). The first industrial nation: The economic history of Britain 1700-1914. London: Routledge.

McKenna, A. J., \& Rodger, R. G. (1985). 'Control by coercion': Employers' associations and the establishment of industrial order in the building industry of England and Wales, 1860-1914. Business History Review, 59(2), 203-231.

Mclvor, A. J. (1983). Employers' associations and industrial relations in Lancashire, 1890-1939. Dissertation, Manchester University.

Mikkelsen, F. (1996). Working-class formation in Europe: In search of a synthesis. Amsterdam: International Institute of Social History.

Nolan, M. (1986). Economic crisis, state policy, and working-class formation in Germany, 1870-1900. In Katznelson \& Zolberg, Working-class formation (pp. 352-393).

Pelling, H. (1987). A history of British trade unionism. Harmondsworth: Penguin.

Pierson, P. (2000). The limits of design: Explaining institutional origins and change. Governance, 13(4), 475-499.

Powell, C. (1996). The British building industry since 1800. An economic history. London: E. \& F.N. Spon.

Prak, M. (1996). Individual, corporation and society: The rhetoric of Dutch guilds (18th. C.). In M. Boone \& M. Prak (Eds.), Individual, corporate, and judicial status in European cities late middle ages and early modern period (pp. 255-279). Louvain/Apeldoorn: Garant.

Prak, M. (1997). Burghers into citizens: Urban and national citizenship in the Netherlands during the revolutionary era (c. 1800). Theory and Society, 26, 403-420.

Prak, M. (2018). Citizens without nations. In Urban citizenship in Europe and the world, 1000-1789. Cambridge: Cambridge University Press.

Prak, M., Lis, C., Lucassen, J., \& Soly, H. (Eds.). (2006). Craft guilds in the early modern. Low Countries: Work, power, and representation. Aldershot: Ashgate.

Price, R. (1990). Britain. In M. van der Linden \& J. Rojahn (Eds.), The formation of labour movements 18701914. An international perspective (Vol. 1, pp. 3-24). Leiden: E.J. Britt.

Prothero, I.J. (1979). Artisans and politics in early nineteenth-century London. John Gast and his times. Folkestone: Wm Dawson \& Son.

Quataert, J. (1985). The shaping of women's work in manufacturing: Guilds, households, and the state in Central Europe, 1648-1870. American Historical Review, 90(5), 1122-1148.

Rokkan, S. (1970). Citizens, elections, parties: Approaches to the comparative study of the processes of development. Oslo: Universitetsforlaget.

Rosser, G. (2015). The art of solidarity in the Middle Ages: Guilds in England 1250-1550. Oxford: Oxford University Press.

Rule, J. (1981). The experience of labour in eighteenth-century industry. London: Croom Helm.

Sabel, C. F., \& Zeitlin, J. (1985). Historical alternatives to mass production: Politics, markets and technology in nineteenth-century industrialization. Past \& Present, 108, 133-176.

Sabel, C. F., \& Zeitlin, J. (2002). Stories, strategies, structures: Rethinking historical alternatives to mass production. In C. F. Sabel \& J. Zeitlin (Eds.), World of possibilities. Flexibility and mass production in Western industrialization (pp. 1-33). Cambridge: Cambridge University Press.

Schalk, R. (2016). Splitting the bill: Matching schooling to Dutch labour markets, 1750-1920. Meppel: Boom.

Scott, W. R. (2008). Institutions and Organizations: Ideas and interests. Thousand Oaks: Sage.

Shin, J.-S. (1996). The economics of the latecomers: Catching-up, technology transfer, and institutions in Germany, Japan, \& South Korea. London: Routledge.

Steinmetz, G. (1993). Regulating the social. The welfare state and local politics in imperial Germany. Princeton: Princeton University Press.

Thelen, K. (2004). How institutions evolve: The political economy of skills in Germany, Britain, the United States and Japan. Cambridge: Cambridge University Press.

Trompetter, C. (1997). Agriculture, proto-industry and mennonite entrepreneurship: A history of the textile industries in Twente 1600-1815. Amsterdam: NEHA.

Van der Does, L. P. (1946). De sociale verzekering. Deel I: De economische beteekenis der sociale zekerheid. Deventer: Kluwer 
Van der Ven, F.J.H.M. (1953). De sociale ontwikkeling van het Brabantse volk. In J.E. de Quay (ed.), Het nieuwe Brabant. Deel II: Het Brabantse volk (pp. 61-127). Den Bosch: Provinciaal Genootschap van Kunsten en Wetenschappen.

Van Genabeek, J. A. G. M. (1994). De afschaffing van de gilden en de voortzetting van hun functies. NEHAJaarboek, 57, 63-90.

Van Gerwen, J., \& Seegers, C. (2003). De industrialisatie van Nederland en het industriële grootbedrijf. NEHA Jaarboek, 66, 138-171.

Van Leeuwen, M. H. D. (2012). Guilds and middle-class welfare, 1550-1800: provisions for burial, sickness, old age, and widowhood. Economic History Review, 65, 61-90.

Van Nederveen Meerkerk, E., Heerma van Voss, L., \& Hiemstra-Kuperus, E. (2010). The Netherlands. In L. Heerma van Voss, E. Hiemstra, \& E. Van Nederveen Meerkerk (Eds.), The Ashgate companion to the history of textile workers, 1650-2000 (pp. 363-398). Ashgate: Aldershot.

Van Nierop, H. F. K. (2007). Popular participation in politics in the Dutch Republic. In P. Blickle (Ed.), Representation, representation, and community (pp. 272-290). Oxford: Clarendon Press.

Van Veen, A. (2013). De Kamers van Arbeid. Experimenten met politieke vertegenwoordiging in Nederland rond 1900. Low Countries Historical Review, 128(2), 31-61.

Van Waarden, F. (1987). Het geheim van Twente. Fabrikantenverenigingen in de oudste grootindustrie van Nederland, 1800-1940. Amersfoort/Leuven.

Van Waarden, F. (2002). Dutch consociationalism and corporatism. A case of institutional persistence. Acta Politica, 37(1-2), 44-67.

Van Zanden, J. L., \& Van Riel, A. (2004). The strictures of inheritance. The Dutch economy in the nineteenth century. Princeton: Princeton University Press.

Webb, S. B. (1980). Tariffs, cartels, technology, and growth in the German steel industry, 1879 to 1914. Journal of Economic History, 40(2), 303-330.

Wels, C. B. (1979). Stemmen en kiezen 1795-1922. Tijdschrift voor geschiedenis, 92, 313-332.

Welskopp, T. (2010). The vision(s) of work in the nineteenth-century German labour movement. In Kocka (ed.), Work in a modern society: The German experience in comparative perspective (pp. 55-72). New York: Berghahn.

Wolthuis, J. (1999). Lower technical education in the Netherlands 1798-1993. The rise and fall of a subsystem. Dissertation University of Groningen

Yarmie, A. H. (1980). Employers' organizations in mid-Victorian England. International Review of Social History, 25, 209-235.

Marcel Hoogenboom is Professor in the Department of Interdisciplinary Social Science at Utrecht University, The Netherlands. His research covers the history of the welfare state, labor history, and comparative welfare state analysis. He has published widely on the origins of the welfare state in Western Europe. One of his key publications is "Transnational unemployment insurance: The inclusion and exclusion of foreign workers in labour unions' unemployment insurance funds in the Netherlands (approx. 1900-1940)." International Review of Social History, 58(2) (2013).

Christopher Kissane works for the Royal Historical Society in London and is a Visiting Fellow in the Department of Economic History at London School of Economics and Political Science. He is the author of Food, Religion and Communities in Early Modern Europe (Bloomsbury 2018), and is a BBC/AHRC New Generation Thinker. His research covers early modern social and cultural history, including food, Reformation, Inquisition, witchcraft, and citizenship. He is also currently working on the history of modern Irish migration.

Maarten Prak is Professor of Economic and Social History at Utrecht University, The Netherlands. He has been a visiting scholar at universities in Cambridge, Exeter, and Münster, at the London School of Economics and Political Science, and at the École des Hautes Études en Sciences Sociales in Paris. He has written widely on citizenship and related topics, and his book Citizens Without Nations: Urban Citizenship and the World, 1000-1789 is being published by Cambridge University Press in October 2018. He published earlier work in Theory and Society in 1991 and 1997.

Patrick Wallis is Professor of Economic History at the London School of Economics and Political Science. $\mathrm{He}$ is an economic and social historian focusing on early modern Europe, with a long-standing interest in understanding how corporate institutions affect the production of human capital and reproduce or reinforce inequalities in labor markets and societies. He is the editor of a forthcoming volume with Cambridge 
University Press on apprenticeship in early modern Europe (2018), which seeks to identify and explore the variations across the continent in training systems and how the institutional, political, and economic differences between countries and cities affects the characteristics of the transition of young people into the skilled workforce.

Chris Minns is Professor in the Economic History Department at the London School of Economics and Political Science. His research interests are in historical labor markets, focusing mainly on issues related to migration, education, and training, and the structure of work and pay. Recent publications include "The price of human capital in a pre-industrial economy: premiums and apprenticeship contracts in $18^{\text {th }}$ Century England," with Patrick Wallis, in Explorations in Economic History (2013); "Institutions, history, and wage bargaining outcomes in the post-World War II era," with Marian Rizov, Business History (2015), and "Reverse assimilation? Immigrants in the Canadian labour market during the Great Depression," with Kris Inwood and Fraser Summerfield, in the European Review of Economic History (2016). 